\title{
Sodium Influx Pathways during and after Anoxia in Rat Hippocampal Neurons
}

\author{
Claire Sheldon, ${ }^{1}$ Abdoullah Diarra, ${ }^{2}$ Y. May Cheng, ${ }^{1}$ and John Church ${ }^{1,2}$ \\ Departments of ${ }^{1}$ Physiology and ${ }^{2}$ Anatomy and Cell Biology, University of British Columbia, Vancouver, British Columbia, Canada V6T 1 Z3
}

\begin{abstract}
Mechanisms that contribute to $\mathrm{Na}^{+}$influx during and immediately after 5 min anoxia were investigated in cultured rat hippocampal neurons loaded with the $\mathrm{Na}^{+}$-sensitive fluorophore sodium-binding benzofuran isophthalate. During anoxia, an influx of $\mathrm{Na}^{+}$in the face of reduced $\mathrm{Na}^{+}, \mathrm{K}^{+}$-ATPase activity caused a rise in $\left[\mathrm{Na}^{+}\right]_{\mathrm{i}}$. After the return to normoxia, $\mathrm{Na}^{+}, \mathrm{K}^{+}$-ATPase activity mediated the recovery of $\left[\mathrm{Na}^{+}\right]_{\mathrm{i}}$ despite continued $\mathrm{Na}^{+}$entry. Sodium influx during and after anoxia occurred through multiple pathways and increased the longer neurons were maintained in culture. Under the experimental conditions used, $\mathrm{Na}^{+}$entry during anoxia did not reflect the activation of ionotropic glutamate receptors, TTX- or lidocaine-sensitive $\mathrm{Na}^{+}$channels, plasmalemmal $\mathrm{Na}^{+} / \mathrm{Ca}^{2+}$ exchange, $\mathrm{Na}^{+} / \mathrm{H}^{+}$exchange, or $\mathrm{HCO}_{3}^{-}$-dependent mechanisms; rather, contributions were received from a $\mathrm{Gd}^{3+}$-sensitive pathway activated by reactive oxygen species and $\mathrm{Na}^{+} / \mathrm{K}^{+} / 2 \mathrm{Cl}^{-}$cotransport in neurons maintained for 6-10 and 11-14 $\mathrm{d}$ in vitro (DIV), respectively. Sodium entry immediately after anoxia was not attributable to the activation of ionotropic glutamate receptors, voltage-activated $\mathrm{Na}^{+}$channels, or $\mathrm{Na}^{+} / \mathrm{K}^{+} / 2 \mathrm{Cl}^{-}$cotransport; rather, it occurred via $\mathrm{Na}^{+} / \mathrm{Ca}^{2+}$ exchange, $\mathrm{Na}^{+} / \mathrm{H}^{+}$exchange, and a $\mathrm{Gd}^{3+}$-sensitive pathway similar to that observed during anoxia; 11-14 DIV neurons received an additional contribution from an $\mathrm{HCO}_{3}^{-}$-dependent mechanism(s). The results provide insight into the intrinsic mechanisms that contribute to disturbed internal $\mathrm{Na}^{+}$homeostasis during and immediately after anoxia in rat hippocampal neurons and, in this way, may play a role in the pathogenesis of anoxic or ischemic cell injury.
\end{abstract}

Key words: anoxia; ischemia; intracellular sodium; $\mathrm{Na}^{+} / \mathrm{K}^{+} / 2 \mathrm{Cl}^{-}$cotransport; $\mathrm{Na}^{+} / \mathrm{Ca}^{2+}$ exchange; $\mathrm{Na}^{+} / \mathrm{H}^{+}$exchange; $\mathrm{Gd}^{3+}$

\section{Introduction}

In neurons of the mammalian CNS, anoxia and ischemia lead to early changes in internal ion homeostasis that are important determinants of subsequent injury and death. Although the contribution of changes in intracellular $\mathrm{Ca}^{2+}\left(\mathrm{Ca}^{2+}{ }_{\mathrm{i}}\right)$ has received particular attention, notably within the framework of the excitotoxic model of injury, early increases in intracellular $\mathrm{Na}^{+}\left(\mathrm{Na}^{+}{ }_{\mathrm{i}}\right)$ also occur and contribute to the pathophysiology of neuronal death (Lipton, 1999; Martinez-Sánchez et al., 2004). Sodium influx increases the demand for cellular ATP to maintain the $\mathrm{Na}^{+}$gradient (Chinopoulos et al., 2000) and may contribute to neuronal injury by promoting, for example, the following: membrane depolarization (Haddad and Jiang, 1993; Calabresi et al., 1999), neuronal swelling (Goldberg and Choi, 1993; Chidekel et al., 1997), reverse-mode glutamate reuptake (Roettger and Lipton, 1996), cytosolic $\mathrm{Ca}^{2+}$ accumulation via reverse-mode $\mathrm{Na}^{+}$/ $\mathrm{Ca}^{2+}$ exchange and/or impaired mitochondrial $\mathrm{Ca}^{2+}$ uptake

Received July 14, 2004; revised 0ct. 30, 2004; accepted Nov. 2, 2004.

This work was supported by a grant-in-aid from the Heart and Stroke Foundation of British Columbia and Yukon. C.S. is a recipient of the Michael Smith Foundation for Health Research Doctoral Research Trainee and the Canadian Institutes of Health Research MD/PhD Studentship awards. Y.M.C. is a recipient of the Michael Smith Foundation for Health Research Junior Graduate Studentship and Natural Sciences and Engineering Research Council of Canada Graduate Scholarship awards.

Correspondence should be addressed to Dr. John Church, Department of Anatomy and Cell Biology, University of British Columbia, 2177 Wesbrook Mall, Vancouver, British Columbia, Canada V6T 1Z3. E-mail: jchurch@interchange.ubc.ca.

A. Diarra's present address: Marine Biological Laboratory, 7 MBL Street, Woods Hole, MA 02543.

D01:10.1523/JNEUROSCI.2829-04.2004

Copyright $\odot 2004$ Society for Neuroscience $\quad$ 0270-6474/04/2411057-13\$15.00/0
(Zhang and Lipton, 1999; Breder et al., 2000; Czyż et al., 2002), $\mathrm{Na}^{+}{ }_{\mathrm{i}}$-dependent increases in NMDA receptor-mediated responses (Yu and Salter, 1998; Manzerra et al., 2001), and the activation of second-messenger pathways (Cooper et al., 1998; Hayasaki-Kajiwara et al., 1999).

Although the detrimental effects of $\mathrm{Na}^{+}$entry are recognized, in contrast to non-neuronal cell types (e.g., cardiac myocytes) (Carmeliet, 1999), the mechanisms that mediate $\mathrm{Na}^{+}$influx in response to anoxia or ischemia in mammalian central neurons remain relatively poorly defined. Although $\mathrm{Na}^{+}$entry attributable to the activation of ionotropic glutamate receptors has received some attention, with conflicting results (cf. Pisani et al., 1998; Chen et al., 1999; Müller and Somjen, 2000; LoPachin et al., 2001), glutamate-mediated excitotoxicity cannot fully account for the direct actions of anoxia or ischemia on neurons, and the potential contribution from mechanisms integral to neurons (i.e., independent from glutamate receptor activation and changes in the external microenvironment) to $\mathrm{Na}^{+}$influx during anoxia or ischemia has not been systematically addressed. Furthermore, despite indications that continued $\mathrm{Na}^{+}$influx after reperfusion may be as damaging as $\mathrm{Na}^{+}$entry during anoxia or ischemia (Lipton, 1999), the pathways that mediate $\mathrm{Na}^{+}$influx after anoxia or ischemia have not been well characterized, and it remains unknown whether these pathways might differ from those active during an insult, as reported for $\mathrm{Ca}^{2+}$ (Silver and Erecińska, 1990, 1992).

We have therefore undertaken an assessment of the intrinsic mechanisms that contribute to $\mathrm{Na}^{+}$influx during and immedi- 
ately after $5 \mathrm{~min}$ anoxia in cultured postnatal rat hippocampal neurons. We find not only that $\mathrm{Na}^{+}$influx during and after anoxia is positively related to the length of time that neurons are maintained in culture but also that different pathways are involved during, compared with immediately after, anoxia.

\section{Materials and Methods}

Cell preparation. Primary cultures of hippocampal neurons from 2- to 4-d-old postnatal Wistar rats (Animal Care Centre, University of British Columbia) were prepared as described previously (Diarra et al., 2001). Briefly, rat pups were anesthetized and decapitated, and the hippocampi were removed. The hippocampi were enzymatically and mechanically dissociated, and the resulting cell suspension was plated at a density of 5-8 $\times 10^{5}$ neurons $/ \mathrm{cm}^{2}$ onto glass coverslips coated with poly-D-lysine and laminin. The initial growth medium was DMEM/F-12 (Invitrogen Canada, Burlington, Ontario, Canada) supplemented with $10 \%$ fetal bovine serum. After $24 \mathrm{hr}$, this medium was fully changed to serum-free Neurobasal medium A. Cultures were fed every $4-5 \mathrm{~d}$ by half-changing the existing medium with fresh Neurobasal medium A. Glial proliferation was inhibited $48 \mathrm{hr}$ after initial plating by adding 5-10 $\mu \mathrm{M}$ cytosine arabinoside.

Solutions and test compounds. The majority of experiments were performed under nominally $\mathrm{HCO}_{3}^{-} / \mathrm{CO}_{2}$-free, HEPES-buffered conditions. Standard $\mathrm{HCO}_{3}^{-} / \mathrm{CO}_{2}$-free perfusion medium contained (mM) 136.5 $\mathrm{NaCl}, 3 \mathrm{KCl}, 2 \mathrm{CaCl}_{2}, 1.5 \mathrm{NaH}_{2} \mathrm{PO}_{4}, 1.5 \mathrm{MgSO}_{4}, 10 \mathrm{D}$-glucose, and 10 HEPES and was titrated with $10 \mathrm{M} \mathrm{NaOH}$ to $\mathrm{pH} 7.35$ at $37^{\circ} \mathrm{C}$. In standard $\mathrm{HCO}_{3}^{-} / \mathrm{CO}_{2}$-buffered medium, HEPES was isosmotically replaced by $\mathrm{NaCl}$ and solutions contained $19.5 \mathrm{~mm} \mathrm{NaHCO}_{3}$, by equimolar substitution for $\mathrm{NaCl}$, together with the constituents listed above ( $\mathrm{pH} 7.35$ at $37^{\circ} \mathrm{C}$ after equilibration with $5 \% \mathrm{CO}_{2} / 95 \%$ air); during perfusion with $\mathrm{HCO}_{3}^{-} / \mathrm{CO}_{2}$-buffered media, the atmosphere in the recording chamber contained $5 \% \mathrm{CO}_{2} / 95 \%$ air. When external $\mathrm{Na}^{+}$was reduced to $2-4 \mathrm{~mm}$, $\mathrm{N}$-methyl-D-glucamine $\left(\mathrm{NMDG}^{+}\right)$was used as a substitute, and solutions were titrated to $\mathrm{pH} 7.35\left(37^{\circ} \mathrm{C}\right)$ with $10 \mathrm{M} \mathrm{HCl}$. For $\mathrm{Ca}^{2+}$-free media, $\mathrm{CaCl}_{2}$ was omitted, $\left[\mathrm{Mg}^{2+}\right]$ was increased to $3.5 \mathrm{~mm}$, and $200 \mu \mathrm{M}$ EGTA was added. In solutions containing $\mathrm{Zn}^{2+}, \mathrm{Gd}^{3+}$, or $\mathrm{Ni}^{2+}$, $\mathrm{NaH}_{2} \mathrm{PO}_{4}$ was omitted and $\mathrm{MgSO}_{4}$ was replaced with $\mathrm{MgCl}_{2}$. All experiments were performed at $37^{\circ} \mathrm{C}$, and neurons were continuously superfused at a rate of $2 \mathrm{ml} / \mathrm{min}$; unless noted otherwise, extracellular $\mathrm{pH}$ $\left(\mathrm{pH}_{\mathrm{o}}\right)$ was 7.35 .

As described previously (Diarra et al., 2001), media used to calibrate sodium-binding benzofuran isophthalate (SBFI)-derived fluorescence ratio measurements contained $0.6 \mathrm{mM} \mathrm{MgCl}_{2}, 0.5 \mathrm{mM} \mathrm{CaCl}_{2}, 10 \mathrm{~mm}$ HEPES, $130 \mathrm{~mm}\left[\mathrm{Na}^{+}\right.$] plus $\left[\mathrm{K}^{+}\right], 100 \mathrm{~mm}$ gluconate, $30 \mathrm{mM} \mathrm{Cl}^{-}$, and 4 $\mu \mathrm{M}$ gramidicin $\mathrm{D}$, titrated with $10 \mathrm{M} \mathrm{KOH}$ to $\mathrm{pH}$ 7.35. In experiments in which seminaphthorhodafluor (SNARF) $\mathrm{pH}$ indicators were used, SNARF-derived fluorescence ratio measurements were calibrated with media containing the same components as the standard HEPES-buffered medium, except for the substitution of K gluconate (130.5 mM) and $\mathrm{Na}$ gluconate $(9 \mathrm{~mm})$ for $\mathrm{NaCl}$ and $\mathrm{KCl}$ and the addition of $10 \mu \mathrm{m}$ nigericin (Sheldon et al., 2004).

Test compounds were obtained from Sigma-Aldrich Canada (Oakville, Ontario, Canada), with the exception of the $R \mathrm{p}$ isomer of adenosine- $3^{\prime}, 5^{\prime}$-cyclic monophosphorothioate (Rp-cAMPS) (Biolog Life Science Institute, La Jolla, CA); arachidonyltrifluoromethyl ketone $\left(\mathrm{AACOCF}_{3}\right)$ (Calbiochem, San Diego, CA); and $(5 S, 10 R)-(+)-5-$ methyl-10,11-dihydro-5H-dibenzo[a,d]cyclohepten-5,10-imine maleate (MK-801), 6-cyano-7-nitroquinoxaline-2,3-dione (CNQX), and 2-[2-[4-(4-nitrobenzyloxy)phenyl] ethyl]isothiourea mesylate (KBR7943) (all from Tocris Cookson, Ellisville, MO).

Induction of anoxia. Anoxia was induced by the addition of 1-2 mM sodium dithionite, an $\mathrm{O}_{2}$ scavenger, to the superfusing medium. Solutions containing $\mathrm{Na}_{2} \mathrm{~S}_{2} \mathrm{O}_{4}$ were prepared immediately before use and bubbled with either 100\% Ar (HEPES-buffered media) or 5\% $\mathrm{CO}_{2} / 95 \%$ $\mathrm{Ar}\left(\mathrm{HCO}_{3}^{-} / \mathrm{CO}_{2}\right.$-buffered media); during perfusion with these media, the atmosphere in the recording chamber was switched to $100 \%$ Ar or $5 \%$ $\mathrm{CO}_{2} / 95 \% \mathrm{Ar}$, respectively. We have previously reported that media containing 1-2 $\mathrm{mM} \mathrm{Na}_{2} \mathrm{~S}_{2} \mathrm{O}_{4}$ have $\mathrm{P}_{\mathrm{O} 2}$ values $<1 \mathrm{mmHg}$ and that the changes in $\mathrm{pH}_{\mathrm{i}}$ evoked by anoxia in rat hippocampal neurons are not secondary to any additional properties of the $\mathrm{O}_{2}$ scavenger (Diarra et al., 1999; Sheldon and Church, 2002). In the present study, we assessed the possibility that $\mathrm{Na}_{2} \mathrm{~S}_{2} \mathrm{O}_{4}$ may induce changes in $\left[\mathrm{Na}^{+}\right]_{\mathrm{i}}$ via mechanisms unrelated to its $\mathrm{O}_{2}$ scavenging property in two ways. First, solutions containing 1-2 $\mathrm{mM} \mathrm{Na} \mathrm{S}_{2} \mathrm{O}_{4}$ were bubbled vigorously with air for 20-30 min, which elevated the $\mathrm{P}_{\mathrm{O} 2}$ in these solutions from $<1$ to $152 \pm 6 \mathrm{mmHg}(n=5)$, as measured with an oxygen electrode ( $\mathrm{ISO}_{2}$; World Precision Instruments, Sarasota, $\mathrm{FL})$. The increase in $\left[\mathrm{Na}^{+}\right]_{\mathrm{i}}$ observed during a 5 min exposure to media containing $1-2 \mathrm{mM} \mathrm{Na}_{2} \mathrm{~S}_{2} \mathrm{O}_{4}$ equilibrated with air was $3 \pm 1 \mathrm{~mm}$ $(n=7)$, significantly $(p<0.05)$ less than the $23 \pm 3 \mathrm{~mm}(n=23)$ increase observed in age-matched sister neurons exposed to media also containing 1-2 $\mathrm{mM} \mathrm{Na}_{2} \mathrm{~S}_{2} \mathrm{O}_{4}$ but equilibrated with $100 \% \mathrm{Ar}$ (see Fig. $1 \mathrm{~A}$ ). Second, standard HEPES-buffered medium was bubbled vigorously with ultra-pure Ar for $>18 \mathrm{hr}$, reducing $\mathrm{P}_{\mathrm{O} 2}$ in the medium to $<1 \mathrm{mmHg}$ (Sheldon and Church, 2002). The increases in $\left[\mathrm{Na}^{+}\right]_{\mathrm{i}}$ observed during a $5 \mathrm{~min}$ exposure to this medium were similar to those measured in age-matched neurons when $\mathrm{P}_{\mathrm{O} 2}$ was reduced to $<1 \mathrm{mmHg}$ by the addition of sodium dithionite (see Fig. $1 B$ ). Thus, the $\left[\mathrm{Na}^{+}\right]_{\mathrm{i}}$ changes evoked by exposure to media containing $1-2 \mathrm{mM} \mathrm{Na}_{2} \mathrm{~S}_{2} \mathrm{O}_{4}$ primarily reflect reductions in $\mathrm{P}_{\mathrm{O} 2}$.

Microspectrofluorimetry. The AM ester forms of the $\mathrm{Na}^{+}$-sensitive fluorophore SBFI and the pH-sensitive fluorophores carboxy SNARF-1 and SNARF-5F were obtained from Molecular Probes (Eugene, OR). Neurons were incubated with $10 \mu \mathrm{M}$ SBFI-AM (in the presence of $0.1 \%$ Pluronic F-127 and $5 \mathrm{mg} / \mathrm{ml}$ bovine serum albumin) for $120-180 \mathrm{~min}$ at $32^{\circ} \mathrm{C}$. In experiments in which $\left[\mathrm{Na}^{+}\right]_{\mathrm{i}}$ and $\mathrm{pH}_{\mathrm{i}}$ were measured concurrently (see below), SBFI-loaded neurons were incubated with $10 \mu \mathrm{M}$ carboxy SNARF-1-AM or SNARF-5F-AM in the presence of $0.1 \%$ Pluronic $\mathrm{F}-127$ for $30 \mathrm{~min}$ at $32^{\circ} \mathrm{C}$. After dye loading, coverslips with cells attached were placed in standard HEPES-buffered medium for $20 \mathrm{~min}$ and then mounted in a temperature-controlled recording chamber. Neurons were superfused for $15 \mathrm{~min}$ with the initial experimental solution at $37^{\circ} \mathrm{C}$ before the start of an experiment.

In the majority of experiments, cells were loaded only with SBFI, and measurements of $\left[\mathrm{Na}^{+}\right]_{\mathrm{i}}$ were performed using the dual-excitation ratio method using an imaging system (Atto Bioscience, Rockville, MD) in conjunction with an Axiovert 135 epifluorescence microscope (Carl Zeiss Canada, Don Mills, Ontario, Canada). As described by Diarra et al. (2001), fluorescence emissions (at $>510 \mathrm{~nm}$ ) were measured by a single intensified charge-coupled device camera from regions of interest placed on individual neuronal somata. Raw emission intensity data at each excitation wavelength (334 and $380 \mathrm{~nm}$ ) were corrected for background fluorescence before the calculation of a ratio. Ratio pairs were acquired at 2-15 sec intervals and analyzed off-line. A one-point calibration technique was used to convert background-corrected SBFI ratio values $\left(\mathrm{BI}_{334} / \mathrm{BI}_{380}\right)$ into $\left[\mathrm{Na}^{+}\right]_{\mathrm{i}}$ values as described previously (Diarra et al., 2001). In brief, at the end of an experiment, neurons loaded with SBFI were exposed to a $\mathrm{pH} 7.35$ medium containing $10 \mathrm{mM} \mathrm{Na}^{+}$and $4 \mu \mathrm{M}$ gramicidin $\mathrm{D}$, and the resulting background-corrected ratio value at 10 $\mathrm{mM}\left[\mathrm{Na}^{+}\right]_{\mathrm{i}}$ was used as a normalization factor for experimentally derived $\mathrm{BI}_{334} / \mathrm{BI}_{380}$ ratio values. Parameters used for the calculation of $\left[\mathrm{Na}^{+}\right]_{\mathrm{i}}$ values were derived from full in situ calibration experiments in which neurons were exposed sequentially to media containing eight different $\left[\mathrm{Na}^{+}\right]$values (Diarra et al., 2001).

In a number of experiments, carboxy SNARF-1 and SNARF-5F were used to measure $\mathrm{pH}_{\mathrm{i}}$ concurrently with changes in $\left[\mathrm{Na}^{+}\right]_{\mathrm{i}}$. In neurons coloaded with SBFI and a SNARF-based fluorophore, ratio pairs were collected continuously by alternating between the dual-excitation and dual-emission modes [for technical details and validation of the technique, see Sheldon et al. (2004)]. In brief, SBFI-derived fluorescence emission intensities were measured with a single camera at $550 \mathrm{~nm}$ during excitation at $334 \mathrm{~nm}$ and then at $380 \mathrm{~nm}$; the excitation wavelength was then changed to $488 \mathrm{~nm}$, and SNARF-derived fluorescence emissions were split by a dichroic mirror centered at $605 \mathrm{~nm}$ and measured by two separate cameras at 550 and $640 \mathrm{~nm}$. Camera registration was confirmed before every experiment. To convert background-corrected, SNARFderived ratio values $\left(\mathrm{BI}_{550} / \mathrm{BI}_{640}\right)$ into $\mathrm{pH}_{\mathrm{i}}$, neurons loaded with a SNARF derivative were exposed at the end of an experiment to a $\mathrm{pH} 7.00$ high- 
Table 1. Effects of various treatments on increases in $\left[\mathrm{Na}^{+}\right]_{\mathrm{i}}$ during anoxia

\begin{tabular}{|c|c|c|}
\hline \multirow[b]{2}{*}{ Treatment } & \multicolumn{2}{|c|}{ Normalized $\Delta\left[\mathrm{Na}^{+}\right]_{\mathrm{i}(\text { during })}$} \\
\hline & $6-10$ DIV & 11-14 DIV \\
\hline $1 \mu \mathrm{M}$ TTX & $1.04 \pm 0.11(5)$ & $0.91 \pm 0.17(5)$ \\
\hline $250 \mu$ m lidocaine & $0.94 \pm 0.12(7)$ & n.d. \\
\hline $50 \mu \mathrm{m}$ bepridil & $0.94 \pm 0.17(7)$ & n.d. \\
\hline $1 \mu \mathrm{m} \mathrm{KB-R7943}$ & $1.05 \pm 0.28(5)$ & n.d. \\
\hline $10 \mu м$ KB-R7943 & $1.02 \pm 0.17(6)$ & n.d. \\
\hline $25 \mu \mathrm{M}$ CGP-37157 & $1.02 \pm 0.28(4)$ & n.d. \\
\hline $0 \mathrm{Ca}^{2+}$ & $0.92 \pm 0.16(5)$ & $1.04 \pm 0.20(4)$ \\
\hline $100 \mu$ m bumetanide & $1.12 \pm 0.19(5)$ & $0.61 \pm 0.05(9)^{*}$ \\
\hline $200 \mu \mathrm{m}$ harmaline ${ }^{a}$ & $0.91 \pm 0.22(7)$ & $0.98 \pm 0.26(5)$ \\
\hline $\mathrm{HCO}_{3}^{-} / \mathrm{CO}_{2}$ buffer & $1.11 \pm 0.13(8)$ & $0.79 \pm 0.13(5)$ \\
\hline $\mathrm{HCO}_{3}^{-} / \mathrm{CO}_{2}$ buffer plus $200 \mu \mathrm{m}$ DIDS & $1.18 \pm 0.28(3)$ & $0.78 \pm 0.31(4)$ \\
\hline
\end{tabular}

Except where noted, experiments were performed under nominally $\mathrm{HCO}_{3}^{-}$-free, $\mathrm{HEPES}$-buffered conditions. To generate normalized $\Delta\left[\mathrm{Na}^{+}\right]_{\text {i(during) }}$ values, measurements of $\Delta\left[\mathrm{Na}^{+}\right]_{\text {i(during) }}$ under a given test condition were normalized to measurements made in control experiments performed on age-matched sister neurons. Statistical comparisons were performed by comparing absolute $\Delta\left[\mathrm{Na}^{+}\right]_{\text {i(during) }}$ measurements made under a given test condition with measurements made in age-matched sister neurons under control conditions. The asterisk indicates statistical significance $(p<0.05)$ compared with measurements made in age-matched sister neurons in the absence of treatment. The numbers in parentheses indicate the number of neuronal populations (i.e. coverslips) from which data were obtained. n.d., Not determined.

${ }^{a}$ Because of its fluorescence properties, neurons were pretreated with harmaline for 60 min before the start of an experiment.

Table 2. Effects of various treatments on increases in $\left[\mathrm{Na}^{+}\right]_{\mathrm{i}}$ after anoxia $\left(\mathrm{Na}^{+}, \mathrm{K}^{+}\right.$ATPase blocked)

\begin{tabular}{|c|c|c|}
\hline \multirow[b]{2}{*}{ Treatment } & \multicolumn{2}{|c|}{ Normalized $\Delta\left[\mathrm{Na}^{+}\right]_{i(\text { after) }}$} \\
\hline & 6-10 DIV & 11-14 DIV \\
\hline $1 \mu \mathrm{M} \mathrm{TTX}$ & $0.98 \pm 0.20(5)$ & $0.92 \pm 0.02(3)$ \\
\hline $100 \mu \mathrm{m} \mathrm{TTX}$ & $0.83 \pm 0.13(4)$ & n.d. \\
\hline $250 \mu \mathrm{m}$ lidocaine & n.d. & $0.89 \pm 0.29(3)$ \\
\hline $100 \mu \mathrm{m}$ bumetanide & $0.91 \pm 0.27(3)$ & $1.21 \pm 0.25(4)$ \\
\hline $50 \mu \mathrm{m}$ bepridil & $0.43 \pm 0.12(6)^{*}$ & n.d. \\
\hline $1 \mu \mathrm{M} \mathrm{KB-R7943}$ & $1.56 \pm 0.25(4)^{*}$ & n.d. \\
\hline $0 \mathrm{Ca}^{2+}$ & $1.75 \pm 0.31(3)^{*}$ & n.d. \\
\hline $10 \mu м$ KB-R7943 & $0.67 \pm 0.09(5)^{*}$ & n.d. \\
\hline
\end{tabular}

$\mathrm{Na}^{+}, \mathrm{K}^{+}$-ATPase activity was blocked immediately after anoxia by perfusion with $\mathrm{K}^{+}$-free medium, except in the case of bumetanide treatment in which $\mathrm{Na}^{+}, \mathrm{K}^{+}$-ATPase was inhibited immediately after anoxia by exposure to 500 $\mu \mathrm{M}$ ouabain. To generate normalized $\Delta\left[\mathrm{Na}^{+}\right]_{\mathrm{i} \text { (after) }}$ values, measurements of $\Delta\left[\mathrm{Na}^{+}\right]_{\text {i(after) }}$ under a given test condition were normalized to measurements made in control experiments performed on age-matched sister neurons. Statistical comparisons were performed by comparing absolute $\Delta\left[\mathrm{Na}^{+}\right]_{i \text { (after) }}$ measurements made under a given test condition with measurements made in age-matched sister neurons under control conditions. The asterisk indicates statistical significance $(p<0.05)$ compared with measurements made in age-matched sister neurons in the absence of treatment. The numbers in parentheses denote the number of neuronal populations (i.e., coverslips) from which the data were obtained. n.d., Not determined.

$\left[\mathrm{K}^{+}\right]$medium containing $10 \mu \mathrm{M}$ nigericin, and the resulting background-corrected ratio value at $\mathrm{pH}_{\mathrm{i}} 7.00$ was used as a normalization factor for experimentally derived $\mathrm{BI}_{550} / \mathrm{BI}_{640}$ ratio values. The constants required to convert experimentally derived $\mathrm{BI}_{550} / \mathrm{BI}_{640}$ ratio values into $\mathrm{pH}_{\mathrm{i}}$ values were determined in full calibration experiments as described previously (Sheldon et al., 2004).

To limit potential cross-contamination by ionophores, perfusion lines were replaced, and the imaging chamber was decontaminated after each experiment.

Data analysis. The magnitude of the increase in $\left[\mathrm{Na}^{+}\right]_{\mathrm{i}}$ during 5 min anoxia $\left(\Delta\left[\mathrm{Na}^{+}\right]_{\mathrm{i} \text { (during) }}\right)$ was measured as the difference between the resting $\left[\mathrm{Na}^{+}\right]_{\mathrm{i}}$ value before anoxia and the peak $\left[\mathrm{Na}^{+}\right]_{\mathrm{i}}$ value reached during anoxia (see Fig. $1 A$ ). To characterize the $\mathrm{Na}^{+}$influx pathways active immediately after anoxia, neurons were exposed to $5 \mathrm{~min}$ anoxia and, after the return to normoxia, $\mathrm{Na}^{+}, \mathrm{K}^{+}$-ATPase activity was inhibited for $7 \mathrm{~min}$ by exposure to $\mathrm{K}^{+}$-free medium or the application of 500 $\mu \mathrm{M}$ ouabain, as described by van Emous et al. (1998). The magnitude of the increase in $\left[\mathrm{Na}^{+}\right]_{\mathrm{i}}$ after anoxia under these conditions $\left(\Delta\left[\mathrm{Na}^{+}\right]_{\mathrm{i}(\text { after })}\right)$ was measured as the difference between the $\left[\mathrm{Na}^{+}\right]_{\mathrm{i}}$ value observed at the end of $5 \mathrm{~min}$ anoxia and the $\left[\mathrm{Na}^{+}\right]_{\mathrm{i}}$ value observed at the end of the 7 min exposure to $0\left[\mathrm{~K}^{+}\right]_{\mathrm{o}}$ or $500 \mu \mathrm{M}$ ouabain (see Fig. $5 A$ ). In experiments in which changes in $\mathrm{pH}_{\mathrm{i}}$ and $\left[\mathrm{Na}^{+}\right]_{\mathrm{i}}$ during and after anoxia were measured concurrently, the magnitude of the fall in $\mathrm{pH}_{\mathrm{i}}$ during anoxia was measured as the difference between the $\mathrm{pH}_{\mathrm{i}}$ value at the end of 5 min anoxia and the preanoxic $\mathrm{pH}_{\mathrm{i}}$ value (see Fig. $8 \mathrm{~A}$ ), and the magnitude of the increase in $\mathrm{pH}_{\mathrm{i}}$ after anoxia $\left(\mathrm{Na}^{+}, \mathrm{K}^{+}\right.$-ATPase inhibited) was measured as the difference between the $\mathrm{pH}_{\mathrm{i}}$ value at the end of 5 min anoxia and the $\mathrm{pH}_{\mathrm{i}}$ value at the end of 7 min exposure to $0\left[\mathrm{~K}^{+}\right]_{\mathrm{o}}$ (see Fig. $8 B$ ).

In light of the findings that the magnitudes of the changes in $\left[\mathrm{Na}^{+}\right]_{\mathrm{i}}$ both during and after anoxia were related to the length of time that neurons had been maintained in culture (see Results), experiments were performed routinely on cultures maintained for $6-10 \mathrm{~d}$ in vitro (DIV) and, where noted, were repeated using 11-14 DIV neuronal cultures. In both groups, measurements of anoxia-evoked changes in $\left[\mathrm{Na}^{+}\right]_{\mathrm{i}} \mathrm{ob}-$ served under a given test condition were normalized to measurements made under control conditions in age-matched sister neurons (yielding normalized $\Delta\left[\mathrm{Na}^{+}\right]_{\mathrm{i}(\text { during) }}$ and $\Delta\left[\mathrm{Na}^{+}\right]_{\mathrm{i} \text { (after) }}$ values) (Tables 1,2$)$. Student's two-tailed unpaired $t$ tests were used to compare statistically the absolute (i.e., not normalized) $\Delta\left[\mathrm{Na}^{+}\right]_{\mathrm{i}(\text { during) }}$ and $\Delta\left[\mathrm{Na}^{+}\right]_{\mathrm{i}(\text { after })}$ measurements made under a given test condition to the respective measurements made in age-matched sister neurons under control conditions; significance was assumed at the $5 \%$ level.

Data are reported as means \pm SEM, with the accompanying $n$ value referring to the number of neuronal populations (i.e., coverslips) from which data were obtained. In studies in which neurons were coloaded with SBFI and either carboxy SNARF-1 or SNARF-5F, experiments were performed on at least three (usually more than five) coverslips obtained from at least three (usually more than four) different batches of neuronal cultures, and the accompanying $n$ value refers to the number of neurons from which data were analyzed.

Intracellular ATP measurements. Cellular ATP content was determined from luciferin-luciferase luminescence, using the ATP determination kit (Molecular Probes). Anoxia was induced in neuronal cultures under conditions identical to those used for the great majority of the microspectrofluorimetric studies (i.e., conditions of constant superfusion at $37^{\circ} \mathrm{C}$, $\mathrm{pH}_{\mathrm{o}}$ 7.35). Before and at fixed time points during and after anoxia, neurons were lysed by the addition of $40 \mu \mathrm{l}$ of $10 \mathrm{~mm}$ Tris buffer, $\mathrm{pH} 7.5$, $0.1 \mathrm{M} \mathrm{NaCl}, 1 \mathrm{~mm}$ EDTA, and $0.01 \%$ Triton X-100 in the presence of a protease inhibitor mixture (Roche Diagnostics, Laval, Quebec, Canada). Aliquots $(10 \mu \mathrm{l})$ were then removed, and sample luminescence was detected with a Berthold LB9507 Lumat luminometer (Fisher Scientific, Ottawa, Ontario, Canada). ATP measurements were made in triplicate on a minimum of four samples at each time point and are reported as percentage declines compared with measurements made before anoxia in paired samples.

\section{Results \\ Changes in $\left[\mathrm{Na}^{+}\right]_{\mathrm{i}}$ during 5 min anoxia}

\section{Characterization of baseline response}

Before anoxia, resting $\left[\mathrm{Na}^{+}\right]_{\mathrm{i}}$ was $11 \pm 1 \mathrm{~mm}(n=444)$, a value similar to those reported previously in mammalian central neurons both in culture (Rose and Ransom, 1997; Chen et al., 1999; Diarra et al., 2001) and in slice preparations (Pisani et al., 1998; Calabresi et al., 1999). Five-minute anoxia evoked an increase in $\left[\mathrm{Na}^{+}\right]_{\mathrm{i}}$ that began $\sim 90 \mathrm{sec}$ after the start of anoxia and recovered to resting levels within $\sim 6-10$ min of the return to normoxia (Fig. $1 A$ ). As illustrated in Figure $1 B$, there was a positive correlation between the magnitude of the increase in $\left[\mathrm{Na}^{+}\right]_{\mathrm{i}}$ observed during anoxia and the length of time neurons had been maintained in culture. The increases in $\left[\mathrm{Na}^{+}\right]_{\mathrm{i}}$ seen during anoxia are broadly consistent with those observed previously in a variety of mammalian central neurons in response to anoxia or oxygenglucose deprivation in vitro (Friedman and Haddad, 1994; Pisani et al., 1998; Calabresi et al., 1999; Diarra et al., 2001) and in CA1 neurons in response to $8 \mathrm{~min}$ global ischemia in vivo (Erecińska and Silver, 2001). When anoxia was imposed under reduced $\left[\mathrm{Na}^{+}\right]_{\mathrm{o}}, \mathrm{NMDG}^{+}$-substituted conditions, the increase in $\left[\mathrm{Na}^{+}\right]_{\mathrm{i}}$ 
was prevented $(n=8)$ (Fig. $1 C$ ), indicating a requirement for $\mathrm{Na}^{+}$entry. In neurons maintained for either $6-10$ or 11-14 DIV, ionotropic glutamate receptor activation did not contribute to the increase in $\left[\mathrm{Na}^{+}\right]_{\mathrm{i}}$ induced by anoxia under the constant superfusion conditions of the present experiments (supplemental Fig. 1, available at www.jneurosci.org as supplemental material).

Consistent with previous findings that the maintenance of resting $\left[\mathrm{Na}^{+}\right]_{\mathrm{i}}$ in rat hippocampal neurons reflects a balance between $\mathrm{Na}^{+}, \mathrm{K}^{+}$-ATPase activity and $\mathrm{Na}^{+}$influx driven by a steep inward electrochemical gradient for $\mathrm{Na}^{+}$(Rose and Ransom, 1997), 5 min applications of $\mathrm{K}^{+}$free medium or $500 \mu \mathrm{M}$ ouabain under normoxic conditions evoked increases in $\left[\mathrm{Na}^{+}\right]_{\mathrm{i}}$ of $26 \pm 5$ and $27 \pm 4 \mathrm{~mm}$, respectively ( $n=6$ neuronal cultures at $6-10$ DIV in each case) (Fig. $2 A$ ). The accumulation of $\mathrm{Na}^{+}{ }_{\mathrm{i}}$ in neurons during anoxia also reflects a balance between reduced $\mathrm{Na}^{+}, \mathrm{K}^{+}$-ATPase activity and ongoing/increased $\mathrm{Na}^{+}$influx. In the present experiments, increases in $\left[\mathrm{Na}^{+}\right]_{\mathrm{i}}$ during anoxia occurred at times at which ATP levels were reduced; after $3 \mathrm{~min}$ anoxia, internal ATP had fallen by $66 \pm 7 \%$, with an additional decrease to $24 \pm 8 \%$ of preanoxic values at the end of 5 min anoxia (Fig. $2 B$ ). When neuronal cultures were incubated with 10 $\mathrm{mm}$ creatine for $2 \mathrm{hr}$ to increase intracellular phosphocreatine levels (Balestrino et al., 2002), the fall in ATP observed after 3 min anoxia under control conditions was attenuated (Fig. 2B) (Sheldon and Church, 2004) and the increase in $\left[\mathrm{Na}^{+}\right]_{\mathrm{i}}$ observed at this time was reduced by $\sim 55 \%$ compared with that seen in agematched sister neurons not pretreated with creatine (Fig. 2C). Creatine pretreatment failed to significantly limit either the fall in internal ATP (Fig. $2 B$ ) or the increase in $\left[\mathrm{Na}^{+}\right]_{\mathrm{i}}$ (Fig. $2 C$ ) seen after 5 min anoxia. For each of these experimental series, qualitatively similar effects were observed in neurons maintained for 11-14 DIV.

Together, these results indicate that the increase in $\left[\mathrm{Na}^{+}\right]_{\mathrm{i}}$ during anoxia under the present experimental conditions reflects reduced $\mathrm{Na}^{+}, \mathrm{K}^{+}$-ATPase activity in the face of an ongoing/increased entry of $\mathrm{Na}^{+}$ions that is not dependent on ionotropic glutamate receptor activation. Therefore, in subsequent experiments, we were able to assess the role of pathways intrinsic to hippocampal neurons in $\mathrm{Na}^{+}$influx during anoxia.

Voltage-activated $\mathrm{Na}^{+}$channels

In whole-cell recordings obtained using the perforated patch (amphotericin B) configuration, the resting membrane potential
$B$
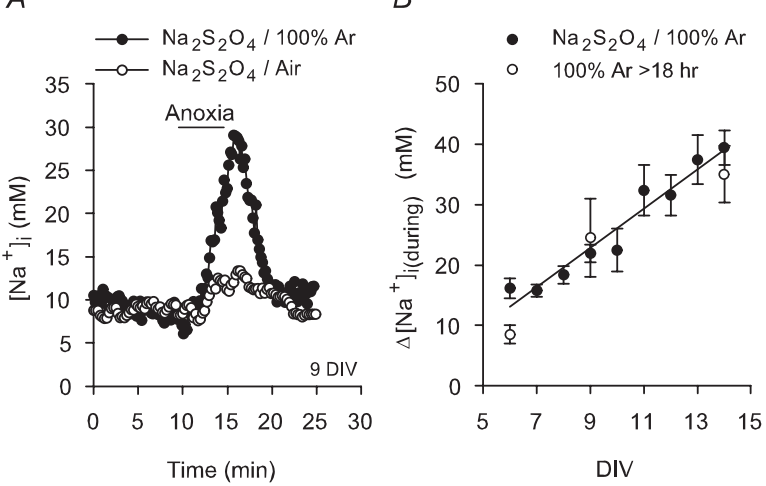

C

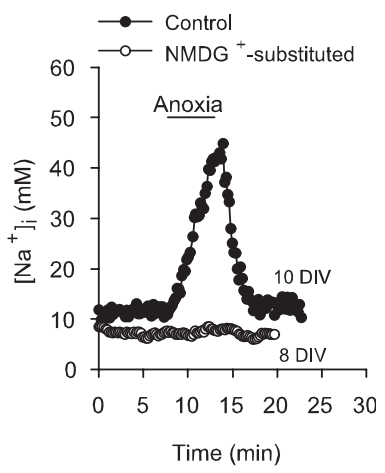

Figure 1. Changes in $\left[\mathrm{Na}^{+}\right]_{\mathrm{i}}$ evoked by 5 min anoxia in cultured postnatal rat hippocampal neurons. $\mathrm{A}$, Anoxia was imposed under nominally $\mathrm{HCO}_{3}^{-} / \mathrm{CO}_{2}$-free, HEPES-buffered conditions by exposure to medium containing 1-2 mm sodium dithionite and bubbled vigorously with $100 \% \operatorname{Ar}(-)$. Also shown are the changes in neuronal $\left[\mathrm{Na}^{+}\right]_{\mathrm{i}}$ evoked by anoxia in an age-matched sister culture exposed to medium containing 1-2 mm sodium dithionite and bubbled vigorously with air $(\bigcirc)$. B, Relationship between the magnitude of the increase in $\left[\mathrm{Na}^{+}\right]_{\mathrm{i}}$ during anoxia $\left(\Delta\left[\mathrm{Na}^{+}\right]_{\mathrm{i} \text { (during) }}\right)$ and the number of days that neurons had been maintained in culture (DIV). Anoxia was imposed under HEPES-buffered conditions either by the addition of sodium dithionite to medium bubbled with $100 \% \operatorname{Ar}(\mathbf{0} ; n=21-54$ for each datum point) or by the exposure to medium that had been bubbled vigorously with $100 \%$ Ar for $>18 \mathrm{hr}(\bigcirc ; n \geq 3$ for each datum point). The solid line represents a linear regression fit to the data points obtained when anoxia was imposed by the addition of sodium dithionite (correlation coefficient, $0.95 ; p<0.0001$ ). C, Under normal $\mathrm{Na}^{+}{ }_{0}$-containing conditions, anoxia induced an increase in $\left[\mathrm{Na}^{+}\right]_{\mathrm{i}}$ that recovered after the return to normoxia $(\mathbf{O})$. When anoxia was imposed under reduced $\mathrm{Na}^{+}{ }_{0}, \mathrm{NMDG}^{+}$-substituted conditions, the increase in $\left[\mathrm{Na}^{+}\right]_{i}$ was inhibited $(\mathrm{O})$.
$A$

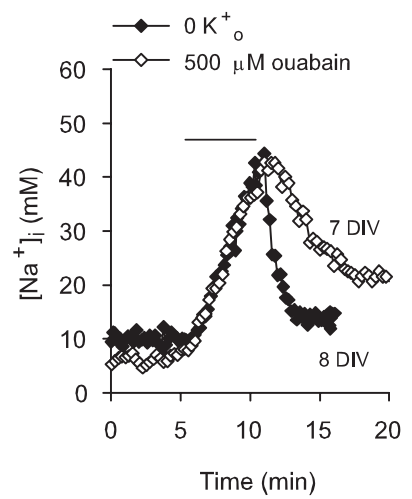

$B$

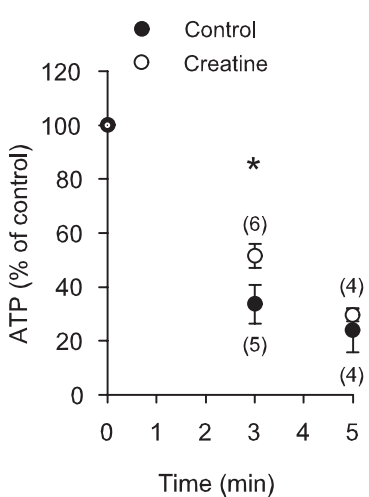

C

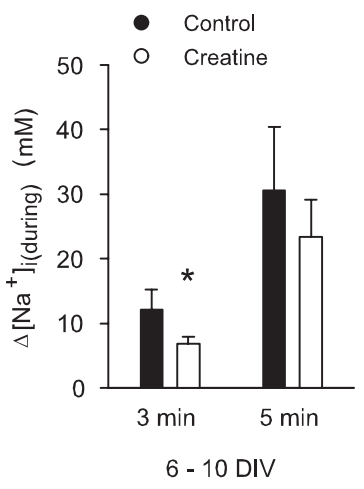

Figure 2. Contribution of reduced $\mathrm{Na}^{+}, \mathrm{K}^{+}$-ATPase activity to the increase in $\left[\mathrm{Na}^{+}\right]_{\mathrm{i}}$ during anoxia. $A$, Superimposed records of the changes in $\left[\mathrm{Na}^{+}\right]_{\mathrm{i}}$ observed under normoxic conditions in response to 5 min exposures to either $\mathrm{K}^{+}$-free medium $(\bullet)$ or normal medium $\left(3 \mathrm{~mm} \mathrm{~K}^{+}\right)$containing $500 \mu \mathrm{m}$ ouabain $(\diamond)$, as indicated by the bar above the traces. $B$, Internal ATP levels were determined after 3 and 5 min anoxia induced by exposure to sodium dithionite-containing medium in 6-10 DIV neurons under control conditions $(-$ or after pretreatment with $10 \mathrm{~mm}$ creatine for $2 \mathrm{hr}(\bigcirc)$. In each experimental group, ATP levels were normalized to preanoxic measurements made in age-matched sister neuronal cultures. The fall in internal ATP levels evoked by 3 min, but not 5 min, anoxia under control conditions was significantly attenuated by creatine pretreatment $\left.{ }^{*} p<0.05\right)$. The numbers in parentheses indicate the number of neuronal populations examined under each experimental condition. C, In neurons pretreated with $10 \mathrm{~mm}$ creatine for $2 \mathrm{hr}(\square)$, the increase in $\left[\mathrm{Na}^{+}\right]_{i}$ measured $3 \mathrm{~min}$ after the start of anoxia was significantly less than that observed under control conditions $\left(\square ;{ }^{*} p<0.05 ; n=6\right.$ neuronal cultures at $6-10$ DIV in each case). The increases in $\left[\mathrm{Na}^{+}\right]_{\mathrm{i}}$ measured after 5 min anoxia under control conditions and in creatine-treated, age-matched sister neurons were not significantly different $(p=0.57)$.

of cultured postnatal rat hippocampal neurons before anoxia was $-63 \pm 2 \mathrm{mV}$, and $5 \mathrm{~min}$ anoxia evoked a depolarization of $24 \pm$ $4 \mathrm{mV}(n=6)$, similar to depolarizations observed by others in a variety of isolated mammalian central neurons in response to 5 min anoxia (Haddad and Jiang, 1993) or 30 min metabolic inhibition (Aarts et al., 2003). However, although $1 \mu \mathrm{M}$ tetrodotoxin (TTX) reduced the increases in $\left[\mathrm{Na}^{+}\right]_{i}$ evoked by $60 \mathrm{sec}$ applications of $50 \mathrm{mM} \mathrm{K}^{+}{ }_{\mathrm{o}}$ under normoxic conditions from $14 \pm 3$ to $2 \pm 1 \mathrm{~mm}(n=6 ; p<0.05)$ (Rose and Ransom, 1997), it failed to 
A

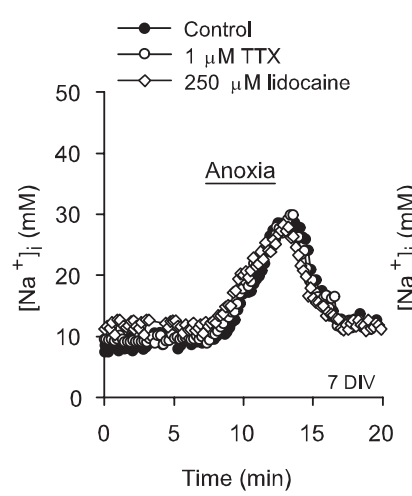

$B$

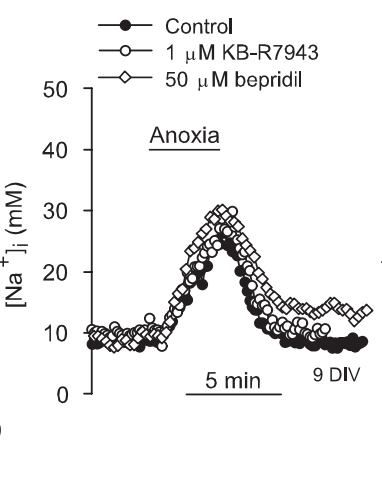

$C$

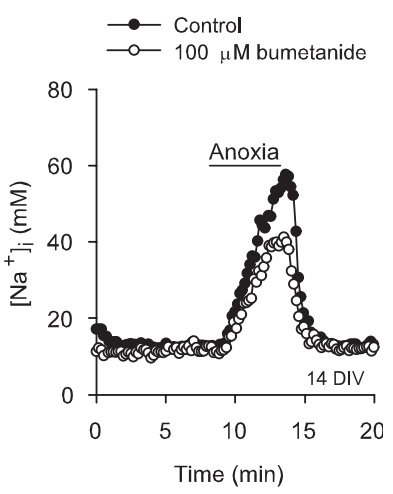

Figure 3. Contribution of voltage-activated $\mathrm{Na}^{+}$channels, $\mathrm{Na}^{+} / \mathrm{Ca}^{2+}$ exchange, and $\mathrm{Na}^{+} / \mathrm{K}^{+} / 2 \mathrm{Cl}^{-}$cotransport to the increase in $\left[\mathrm{Na}^{+}\right]_{\mathrm{i}}$ during anoxia. Shown are superimposed records of the changes in $\left[\mathrm{Na}^{+}\right]_{i}$ observed in response to 5 min anoxia imposed in age-matched sister neurons under control conditions $(\mathbf{)}$ and in the presence of an experimental treatment (open symbols); pharmacological inhibitors were present throughout the duration of the traces shown. $A$, Neither $1 \mu \mathrm{m} \mathrm{TTX} \mathrm{nor} 250 \mu \mathrm{M}$ lidocaine affected the increase in $\left[\mathrm{Na}^{+}\right]_{\mathrm{i}}$ during anoxia. $B$, Neither $1 \mu \mathrm{m} \mathrm{KB-R7943} \mathrm{nor} 50 \mu \mathrm{m}$ bepridil exerted a significant effect on the increase in $\left[\mathrm{Na}^{+}\right]_{\mathrm{i}}$ during anoxia. $C$, A concentration of $100 \mu \mathrm{m}$ bumetanide significantly reduced the rise in $\left[\mathrm{Na}^{+}\right]_{\mathrm{i}}$ during anoxia in 14 DIV neurons. See also Table 1.

affect the magnitudes of anoxia-induced increases in $\left[\mathrm{Na}^{+}\right]_{\mathrm{i}}$ in neurons maintained for either $6-10$ or 11-14 DIV (Table 1, Fig. $3 A)$. Lidocaine $(250 \mu \mathrm{M})$ also failed to significantly affect the rise in $\left[\mathrm{Na}^{+}\right]_{\mathrm{i}}$ during anoxia (Table 1, Fig. $3 A$ ), suggesting that TTXresistant $\mathrm{Na}^{+}$channels do not contribute to $\mathrm{Na}^{+}$influx at this time.

\section{Plasmalemmal $\mathrm{Na}^{+} / \mathrm{Ca}^{2+}$ exchange and}

$\mathrm{Na}^{+} / \mathrm{K}^{+} / 2 \mathrm{Cl}^{-}$cotransport

Although the increase in $\left[\mathrm{Ca}^{2+}\right]_{\mathrm{i}}$ observed in cultured postnatal rat hippocampal neurons during $5 \mathrm{~min}$ anoxia (Diarra et al., 1999) could activate forward-mode $\mathrm{Na}^{+} / \mathrm{Ca}^{2+}$ exchange and thereby contribute to $\mathrm{Na}^{+}$influx, a rise in $\left[\mathrm{Na}^{+}\right]_{\mathrm{i}}$ could promote reverse-mode operation of the exchanger and thus $\mathrm{Na}^{+}$efflux. Forward- and reverse-mode operation of the plasmalemmal $\mathrm{Na}^{+} / \mathrm{Ca}^{2+}$ exchanger can be inhibited with bepridil $(50 \mu \mathrm{M})$ and KB-R7943 (1 $\mu \mathrm{M})$, respectively, whereas higher concentrations of KB-R7943 $(10 \mu \mathrm{M})$ inhibit both forward and reverse $\mathrm{Na}^{+} / \mathrm{Ca}^{2+}$ exchange in rat hippocampal neurons (Breder et al., 2000). In the present study, neither bepridil $(50 \mu \mathrm{M})$ nor KB-R7943 (1 or $10 \mu \mathrm{M})$ significantly influenced the magnitude of the increase in $\left[\mathrm{Na}^{+}\right]_{\mathrm{i}}$ during anoxia (Table 1, Fig. 3B). 7-Chloro-5-(2-chlorophenyl)-1,5-dihydro-4,1-benzothiazepin-2(3H)-one (CGP37157) $(25 \mu \mathrm{M})$, which has been reported to inhibit both mitochondrial and plasmalemmal $\mathrm{Na}^{+} / \mathrm{Ca}^{2+}$ exchange (Blaustein and Lederer, 1999; Czyż and Kiedrowski, 2003), or the removal of external $\mathrm{Ca}^{2+}$ similarly failed to modulate the increase in $\left[\mathrm{Na}^{+}\right]_{\mathrm{i}}$ during anoxia (Table 1).

To assess the potential contribution of $\mathrm{Na}^{+} / \mathrm{K}^{+} / 2 \mathrm{Cl}^{-}$cotransport, neurons were pretreated for 10 min with $100 \mu \mathrm{M} \mathrm{bu}$ metanide, which has previously been found to inhibit $\mathrm{Na}^{+} / \mathrm{K}^{+} /$ $2 \mathrm{Cl}^{-}$cotransport in cultured rat cortical neurons (Sun and Murali, 1999). Given that $\mathrm{Na}^{+} / \mathrm{K}^{+} / 2 \mathrm{Cl}^{-}$cotransporter expression increases with time in rat brain (Plotkin et al., 1997) and in cultured neurons (Sun and Murali, 1999), the effects of bumetanide were examined in 6-10 and 11-14 DIV neurons. Bumetanide did not affect resting $\left[\mathrm{Na}^{+}\right]_{\mathrm{i}}$ in either $6-10(n=5)$ or 11-14 ( $n=9$ ) DIV neurons (Rose and Ransom, 1997) and failed to significantly influence the increase in $\left[\mathrm{Na}^{+}\right]_{\mathrm{i}}$ during anoxia in 6-10 DIV neurons (Table 1). In contrast, in 11-14 DIV neurons, bumetanide caused an $\sim 40 \%$ reduction in the rise in $\left[\mathrm{Na}^{+}\right]_{\mathrm{i}}$

during anoxia (Table 1, Fig. 3C). Although $100 \mu \mathrm{M}$ bumetanide may inhibit $\mathrm{Cl}^{-} /$ $\mathrm{HCO}_{3}^{-}$exchange and $\mathrm{K}^{+} / 2 \mathrm{Cl}^{-}$cotransport (Russell, 2000), there are no indications that these mechanisms contribute to changes in $\mathrm{Na}^{+}{ }_{\mathrm{i}}$ homeostasis during brief periods of anoxia or ischemia (Diarra et al., 1999; Sheldon and Church, 2002; Payne et al., 2003).

\section{$p H_{i}$-regulating mechanisms}

Proton-equivalent efflux by the major acid extrusion mechanisms present in rat hippocampal neuron somata, $\mathrm{Na}^{+} / \mathrm{H}^{+}$exchange, and $\mathrm{Na}^{+}$-dependent $\mathrm{Cl}^{-} / \mathrm{HCO}_{3}^{-}$ exchange (Raley-Susman et al., 1991; Schwiening and Boron, 1994; Baxter and Church, 1996) is accompanied by $\mathrm{Na}^{+}$influx (Canzoniero et al., 1996; Rose and Ransom, 1997; Sheldon et al., 2004).

In the absence of a selective pharmacological inhibitor of $\mathrm{Na}^{+} / \mathrm{H}^{+}$exchange in rat hippocampal neurons (Raley-Susman et al., 1991; Schwiening and Boron, 1994; Baxter and Church, 1996), the transport mechanism was inhibited with harmaline, a nonselective agent that has previously been found to inhibit not only functional $\mathrm{Na}^{+} / \mathrm{H}^{+}$exchange activity in rat hippocampal neurons (Raley-Susman et al., 1991) but also the activities of the $\mathrm{Na}^{+} / \mathrm{H}^{+}$exchanger (NHE) isoforms likely to mediate this activity under conditions of normal osmolarity (i.e., NHE1 and NHE5) (Orlowski, 1993; Attaphitaya et al., 1999; Szabó et al., 2000; Douglas et al., 2001). Initially, we confirmed that pretreatment with $200 \mu \mathrm{M}$ harmaline inhibited $\mathrm{Na}^{+} / \mathrm{H}^{+}$exchange activity under our experimental conditions by measuring rates of $\mathrm{pH}_{\mathrm{i}}$ recovery from $\mathrm{NH}_{4}{ }^{+}$-induced internal acid loads imposed under normoxic nominally $\mathrm{HCO}_{3}^{-} / \mathrm{CO}_{2}$-free, HEPES-buffered conditions (see Fig. 7A, inset). However, consistent with previous suggestions (made on the basis of $\mathrm{pH}_{\mathrm{i}}$ measurements) that $\mathrm{Na}^{+} / \mathrm{H}^{+}$ exchange activity in rat hippocampal neurons becomes inhibited soon after the onset of anoxia (Diarra et al., 1999; Sheldon and Church, 2004), harmaline pretreatment failed to limit the rise in $\left[\mathrm{Na}^{+}\right]_{\mathrm{i}}$ during 5 min anoxia in either $6-10$ or 11-14 DIV neurons (Table 1).

The potential contribution of $\mathrm{HCO}_{3}^{-}$-dependent mechanisms to anoxia-induced increases in $\left[\mathrm{Na}^{+}\right]_{i}$ was examined by measuring changes in $\left[\mathrm{Na}^{+}\right]_{\mathrm{i}}$ during anoxia under $\mathrm{HCO}_{3}^{-}$-containing conditions. As reported previously (Rose and Ransom, 1997), the transition from a $\mathrm{HCO}_{3}^{-}$-free, HEPES-buffered medium to a $\mathrm{HCO}_{3}^{-} / \mathrm{CO}_{2}$-buffered medium $\left(\mathrm{pH}_{\mathrm{o}}\right.$ constant at 7.35$)$ caused a small $(\sim 3 \mathrm{mM})$ increase in $\left[\mathrm{Na}^{+}\right]_{\mathrm{i}}$, consistent with the activation of $\mathrm{Na}^{+}$-dependent $\mathrm{Cl}^{-} / \mathrm{HCO}_{3}^{-}$exchange. However, the increases in $\left[\mathrm{Na}^{+}\right]_{\mathrm{i}}$ during 5 min anoxia imposed in the presence of $\mathrm{HCO}_{3}^{-}$were not significantly different from those observed in age-matched sister neurons at 6-10 or 11-14 DIV under $\mathrm{HCO}_{3}^{-}$free conditions (Table 1). In addition, the application of $200 \mu \mathrm{M}$ DIDS under $\mathrm{HCO}_{3}^{-} / \mathrm{CO}_{2}$-buffered conditions failed to limit the rise in $\left[\mathrm{Na}^{+}\right]_{\mathrm{i}}$ during anoxia (Table 1), further suggesting that $\mathrm{HCO}_{3}^{-}$-dependent, $\mathrm{pH}_{\mathrm{i}}$-regulating transport mechanisms do not contribute significantly to the increase in $\left[\mathrm{Na}^{+}\right]_{i}$ during anoxia in rat hippocampal neurons.

Nonselective cation channels

During anoxia or ischemia, increases in $\left[\mathrm{Ca}^{2+}\right]_{i}$ or free radical production can activate nonselective cation channels (NSCCs) 
that in turn may contribute to the pathogenesis of injury (Chen et al., 1999; Barros et al., 2001; Aarts et al., 2003). To examine the contribution of $\mathrm{Na}^{+}$influx through NSCCs to the rise in $\left[\mathrm{Na}^{+}\right]_{\mathrm{i}}$ during anoxia, we applied $\mathrm{Gd}^{3+}$ (Caldwell et al., 1998).

Five to $20 \mathrm{~min}$ exposures to 30 or 100 $\mu \mathrm{M} \mathrm{Gd}^{3+}$ did not affect resting $\left[\mathrm{Na}^{+}\right]_{\mathrm{i}}$ but reduced the magnitude of the increase in $\left[\mathrm{Na}^{+}\right]_{\mathrm{i}}$ during anoxia in 6-10 DIV neurons by $\sim 40 \%$ (Fig. $4 A, B$ ). The finding presented above that the increase in $\left[\mathrm{Na}^{+}\right]_{\mathrm{i}}$ during anoxia was not attenuated in the absence of external $\mathrm{Ca}^{2+}$ suggests that the effect of $\mathrm{Gd}^{3+}$ is unlikely to be mediated via an inhibition of NSCCs activated by increases in $\left[\mathrm{Ca}^{2+}\right]_{\mathrm{i}}$ (we were unable to assess the effect of flufenamate, an inhibitor of $\mathrm{Ca}^{2+}{ }_{\mathrm{i}}$-activated NSCCs, on the increase in $\left[\mathrm{Na}^{+}\right]_{\mathrm{i}}$ during anoxia because it evoked variable increases in resting $\left.\left[\mathrm{Na}^{+}\right]_{\mathrm{i}}\right)$. In addition, neither the broad spectrum voltage-activated $\mathrm{Ca}^{2+}$ channel blocker $\mathrm{Ni}^{2+}$ nor the L-type $\mathrm{Ca}^{2+}$ channel blockers verapamil and nifedipine significantly influenced the increase in $\left[\mathrm{Na}^{+}\right]_{\mathrm{i}}$ during anoxia (Fig. 4B). CNQX $(20 \mu \mathrm{M})$, applied alone (supplemental Fig. 1, available at www.jneurosci.org as supplemental material) or in the presence of the broad spectrum high-voltage-activated $\mathrm{Ca}^{2+}$ channel blocker loperamide $\left(\begin{array}{lll}50 & \mu \mathrm{M}\end{array}\right)$ (Church et al., 1994) (Fig. 4B), also failed to influence the increase in $\left[\mathrm{Na}^{+}\right]_{\mathrm{i}}$ during anoxia. Together, these findings indicate that the effect of $\mathrm{Gd}^{3+}$ to limit $\mathrm{Na}^{+}$influx during anoxia is likely independent of its ability to block voltage-activated $\mathrm{Ca}^{2+}$ channels (Boland et al., 1991) or AMPA/kainate receptors (Lei and MacDonald, 2001) (see also Caldwell et al., 1998).

To examine the potential role of NSCCs activated by reactive oxygen species (ROS) in the effect of $\mathrm{Gd}^{3+}$ to reduce $\mathrm{Na}^{+}$influx during anoxia, neurons were treated with the antioxidant 6-hydroxy-2,5,7,8-tetramethylchroman-2-carboxylate (trolox) for 2-3 hr before anoxia. After pretreatment with $1 \mathrm{~mm}$ trolox (Chow et al., 1994; Brookes et al., 1998; Vergun et al., 2001; Aarts et al., 2003), the magnitude of the increase in $\left[\mathrm{Na}^{+}\right]_{\mathrm{i}}$ during anoxia in 6-10 DIV neurons was reduced by $\sim 40 \%$ (Fig. $4 C$ ). Pretreatment with $200 \mu \mathrm{M}$ trolox elicited similar effects in both 6-10 DIV neurons (Fig. 4D) and 11-14 DIV neurons (the normalized $\Delta\left[\mathrm{Na}^{+}\right]_{\mathrm{i} \text { (during) }}$ value after pretreatment with $200 \mu \mathrm{M}$ trolox in 11-14 DIV neurons was $0.51 \pm 0.18 ; n=4 ; p<0.05)$. In neurons pretreated with trolox, $\mathrm{Gd}^{3+}$ failed to exert an additional inhibitory effect (Fig. 4C,D), supporting the possibility that NSCCs activated by ROS may contribute to $\mathrm{Na}^{+}$influx during anoxia. However, neither $20 \mathrm{~min}$ pretreatment with $500 \mu \mathrm{M}$ $N^{\mathrm{G}}$-nitro-L-arginine methyl ester hydrochloride (L-NAME) or 15-30 $\mu \mathrm{M} \mathrm{AACOCF}{ }_{3}$ significantly affected the increase in $\left[\mathrm{Na}^{+}\right]_{\mathrm{i}}$ (Fig. 4D), suggesting a lack of involvement of nitric oxide synthase (NOS) and cytosolic phospholipase $\mathrm{A}_{2}\left(\mathrm{cPLA}_{2}\right)$, respectively, in the generation of the ROS involved. We were unable to examine the potential effects of manganese (III) tetrakis (4benzoic acid) porphyrin ( $a \mathrm{O}_{2}^{-}$scavenger) or mepacrine (a non-
B

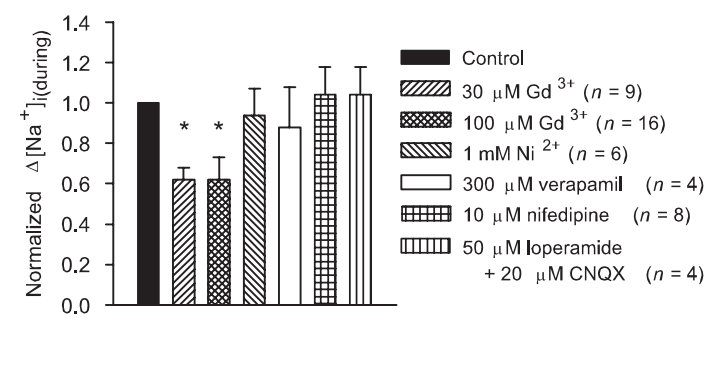

$D$

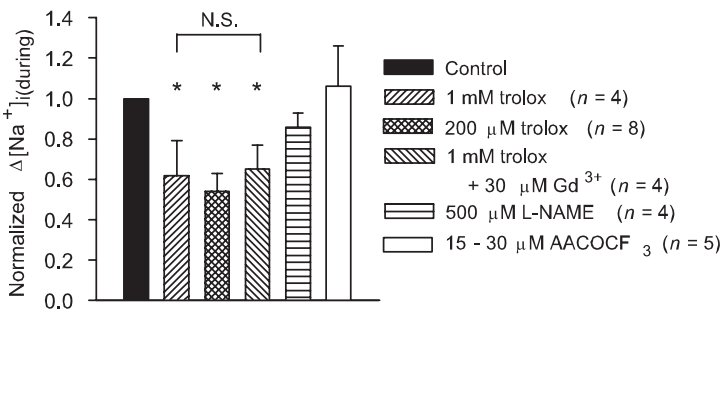




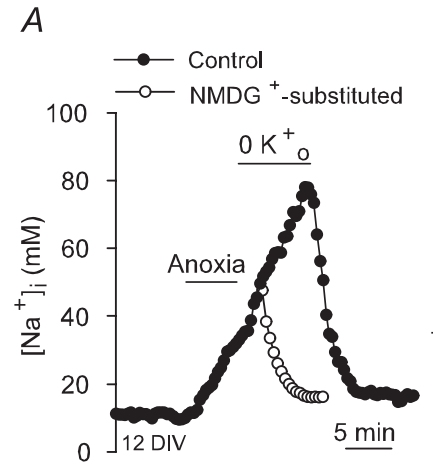

$B$

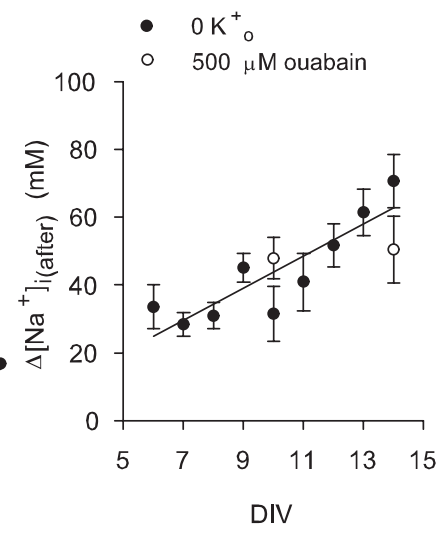

Figure 5. Changes in $\left[\mathrm{Na}^{+}\right]_{\mathrm{i}}$ after anoxia. $A, \mathrm{Na}^{+}, \mathrm{K}^{+}$-ATPase activity was inhibited by perfusion with $\mathrm{K}^{+}$-free medium at the end of 5 min anoxia, revealing a secondary rise in $\left[\mathrm{Na}^{+}\right]_{\mathrm{i}}$ in the immediate postanoxic period (O). Age-matched sister neurons on a different coverslip were exposed to $\mathrm{K}^{+}$- and $\mathrm{Na}^{+}$-free medium after 5 min anoxia imposed under control conditions (O); in the absence of external $\mathrm{Na}^{+}$(NMDG ${ }^{+}$-substituted), the increase in $\left[\mathrm{Na}{ }^{+}\right]_{i}$ after anoxia was abolished. $B$, Relationship between the magnitude of the increase in $\left[\mathrm{Na}^{+}\right]_{i}$ after anoxia $\left(\Delta\left[\mathrm{Na}^{+}\right]_{\mathrm{i}(\text { after })}\right)$ and the number of days neurons had been maintained in culture (DIV). $\Delta\left[\mathrm{Na}^{+}\right]_{\mathrm{i}(\text { after) }}$ was determined as the difference between the $\left[\mathrm{Na}^{+}\right]_{\mathrm{i}}$ value observed at the end of 5 min anoxia and the $\left[\mathrm{Na}^{+}\right]_{\mathrm{i}}$ value observed at the end of 7 min superfusion with $\mathrm{K}^{+}$-free medium $(n=7-31$ for each datum point). The solid line represents the linear regression fit to the data points indicated (correlation coefficient, 0.88; $p<0.0001$ ). Also shown are $\Delta\left[\mathrm{Na}^{+}\right]_{\mathrm{i}(\text { after })}$ values obtained when $\mathrm{Na}^{+}, \mathrm{K}^{+}$-ATPase activity was inhibited for 7 min with $500 \mu$ m ouabain $(\bigcirc ; n=3$ for each datum point).

ATPase activity acts to lower $\left[\mathrm{Na}^{+}\right]_{\mathrm{i}}$ to resting levels despite continued $\mathrm{Na}^{+}$entry. The positive relationship between the rise in $\left[\mathrm{Na}^{+}\right]_{\mathrm{i}}\left(\mathrm{Na}^{+}, \mathrm{K}^{+}\right.$-ATPase blocked $)$after anoxia and the length of time that neurons had been maintained in culture could reflect, for example, developmental upregulation of the pathways that contribute to $\mathrm{Na}^{+}$influx after anoxia (see below) or the intracellular signaling cascades that regulate their activities (Durkin et al., 1997). In subsequent experiments, to characterize the pathways that contribute to $\mathrm{Na}^{+}$influx after 5 min anoxia, $\mathrm{Na}^{+}, \mathrm{K}^{+}$ATPase was blocked for $7 \mathrm{~min}$ immediately after the return to normoxia (van Emous et al., 1998).

\section{Ionotropic glutamate receptor-operated and voltage-activated} $\mathrm{Na}^{+}$channels

Analogous to findings made during anoxia, $2 \mu \mathrm{M}$ MK-801 and 20 $\mu \mathrm{M}$ CNQX failed to significantly affect the increase in $\left[\mathrm{Na}^{+}\right]_{\mathrm{i}}$ observed after anoxia under conditions of $\mathrm{Na}^{+}, \mathrm{K}^{+}$-ATPase inhibition (supplemental Fig. 1, available at www.jneurosci.org as supplemental material). Similarly, $1 \mu \mathrm{M}$ TTX failed to reduce the increase in $\left[\mathrm{Na}^{+}\right]_{\mathrm{i}}$ after anoxia in 6-10 and 11-14 DIV neurons (Table 2). TTX $(100 \mu \mathrm{M})$ and lidocaine $(250 \mu \mathrm{M})$ were also without significant effects in 6-10 and 11-14 DIV neurons, respectively (Table 2 ), suggesting that TTX-resistant $\mathrm{Na}^{+}$channels do not contribute to $\mathrm{Na}^{+}$influx in the immediate postanoxic period.

\section{$\mathrm{Na}^{+} / \mathrm{K}^{+} / 2 \mathrm{Cl}^{-}$cotransport and plasmalemmal}

$\mathrm{Na}^{+} / \mathrm{Ca}^{2+}$ exchange

In contrast to findings made in 11-14 DIV neurons during anoxia (Table 1), $100 \mu \mathrm{M}$ bumetanide failed to significantly reduce the increase in $\left[\mathrm{Na}^{+}\right]_{\mathrm{i}}$ after anoxia in either $6-10$ or $11-14$ DIV neuronal cultures (Table 2). The tendency for bumetanide to augment the rise in $\left[\mathrm{Na}^{+}\right]_{\mathrm{i}}$ after anoxia in $11-14$, but not $6-10$, DIV hippocampal neurons (Table 2) may reflect the finding in

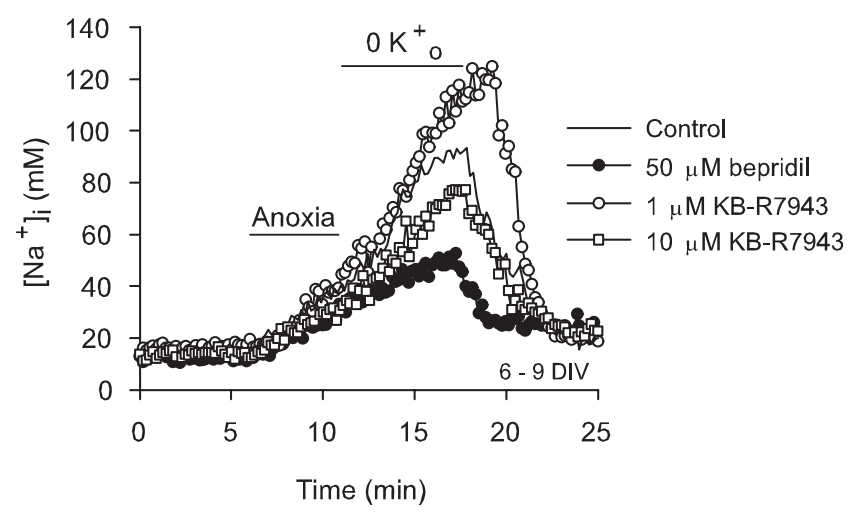

Figure 6. Effects of pharmacological modulators of $\mathrm{Na}^{+} / \mathrm{Ca}^{2+}$ exchange activity on increases in $\left[\mathrm{Na}^{+}\right]_{\mathrm{i}}$ after anoxia $\left(\mathrm{Na}^{+}, \mathrm{K}^{+}\right.$-ATPase inhibited). Neurons were exposed to $\mathrm{K}^{+}$-free medium for $7 \mathrm{~min}$ at the end of $5 \mathrm{~min}$ anoxia. Compared with the increase in $\left[\mathrm{Na}^{+}\right]_{i}$ observed under control conditions $(-)$, the increase in $\left[\mathrm{Na}^{+}\right]_{\mathrm{i}}$ after anoxia was reduced in the presence of $50 \mu \mathrm{m}$ bepridil ( $)$ or $10 \mu \mathrm{M} \mathrm{KB}-\mathrm{R} 7943(\square)$ and was enhanced in the presence of $1 \mu \mathrm{M}$ KB-R7943 (O). Pharmacological treatments began at the end of 5 min anoxia and were continued for the duration of the records shown. See also Table 2.

cardiac myocytes that $\mathrm{Na}^{+} / \mathrm{K}^{+} / 2 \mathrm{Cl}^{-}$cotransport contributes to $\mathrm{Na}^{+}$efflux at reperfusion (Anderson et al., 1996).

$\mathrm{Na}^{+} / \mathrm{Ca}^{2+}$ exchange, operating in forward mode, may mediate $\mathrm{Ca}^{2+}$ efflux after anoxia or ischemia (Breder et al., 2000) and thereby contribute to $\mathrm{Na}^{+}$influx at this time. Conversely, the present experimental conditions (in which $\left[\mathrm{Na}^{+}\right]_{\mathrm{i}}$ after anoxia was maintained at a relatively high level) could favor reversemode operation of the exchange mechanism and thus $\mathrm{Na}^{+}$efflux (Czyż et al., 2002). Applied immediately after anoxia under conditions in which $\mathrm{Na}^{+}, \mathrm{K}^{+}$-ATPase was inhibited, $50 \mu \mathrm{M}$ bepridil significantly reduced the increase in $\left[\mathrm{Na}^{+}\right]_{\mathrm{i}}$ (Table 2, Fig. 6), suggesting that forward-mode $\mathrm{Na}^{+} / \mathrm{Ca}^{2+}$ exchange contributes to $\mathrm{Na}^{+}$influx immediately after anoxia. In contrast, KB-R7943 (1 $\mu \mathrm{M})$ or the removal of external $\mathrm{Ca}^{2+}$ at reoxygenation enhanced the increase in $\left[\mathrm{Na}^{+}\right]_{\mathrm{i}}$ (Table 2, Fig. 6), suggesting that some $\mathrm{Na}^{+} / \mathrm{Ca}^{2+}$ exchangers may be operating in reverse mode to promote $\mathrm{Na}^{+}$efflux at this time. Finally, when applied at $10 \mu \mathrm{M}$ to inhibit both forward- and reverse-mode $\mathrm{Na}^{+} / \mathrm{Ca}^{2+}$ exchange, $\mathrm{KB}-\mathrm{R} 7943$ reduced the increase in $\left[\mathrm{Na}^{+}\right]_{\mathrm{i}}$ after anoxia compared with the increase observed in age-matched sister neurons under control conditions (Table 2, Fig. 6). Together, these results are consistent with those of White and Reynolds (1995), who reported considerable variability in the contribution of forwardmode $\mathrm{Na}^{+} / \mathrm{Ca}^{2+}$ exchange to the recovery of $\left[\mathrm{Ca}^{2+}\right]_{\mathrm{i}}$ after glutamate stimulation in rat forebrain neurons, and those of Yu and Choi (1997), who suggested the possibility that both forward and reverse $\mathrm{Na}^{+} / \mathrm{Ca}^{2+}$ exchange can take place concurrently in the same cell. These issues are considered further in Discussion.

$\mathrm{Na}^{+} / \mathrm{H}^{+}$exchange

Although $\mathrm{Na}^{+} / \mathrm{H}^{+}$exchange in rat hippocampal neurons is inhibited during anoxia, $\mathrm{pH}_{\mathrm{i}}$ measurements indicate that the transporter is activated immediately after reoxygenation (Diarra et al., 1999; Sheldon and Church, 2002) and thus may contribute to $\mathrm{Na}^{+}$influx at this time. Consistent with this possibility, harmaline pretreatment significantly reduced the increase in $\left[\mathrm{Na}^{+}\right]_{\mathrm{i}}$ after anoxia in 6-10 and 11-14 DIV neurons (Fig. 7A,C). Although harmaline also affects voltage-gated $\mathrm{Na}^{+}$channels (Deecher et al., 1992) and $\mathrm{Na}^{+}, \mathrm{K}^{+}$-ATPase (Kim et al., 1988), conventional inhibitors of voltage-gated $\mathrm{Na}^{+}$channels failed to influence the rise in $\left[\mathrm{Na}^{+}\right]_{\mathrm{i}}$ after anoxia (see above), and harmaline reduced $\mathrm{Na}^{+}$entry after anoxia under conditions in which 
$\mathrm{Na}^{+}, \mathrm{K}^{+}$-ATPase activity was already blocked. Intracellular $\mathrm{pH}$ measurements also indicate that $\mathrm{Na}^{+} / \mathrm{H}^{+}$exchange activity in rat hippocampal neurons after anoxia is attenuated at $\mathrm{pH}_{\mathrm{o}} 6.60$ or by inhibition of the cAMP-protein kinase A (PKA) pathway and is augmented at $\mathrm{pH}_{\mathrm{o}} 7.80$ (Diarra et al., 1999; Sheldon and Church, 2002). In the present study, $\mathrm{pH}_{\mathrm{o}} 6.60$ conditions or the PKA inhibitor Rp-cAMPS reduced the rise in $\left[\mathrm{Na}^{+}\right]_{\mathrm{i}}$ after anoxia, whereas, at $\mathrm{pH}_{\mathrm{o}}$ 7.80, the increase in $\left[\mathrm{Na}^{+}\right]_{\mathrm{i}}$ was enhanced (Fig. $7 C$ ). We also reported previously that a $\mathrm{Zn}^{2+}$-sensitive $\mathrm{H}^{+}$efflux pathway contributes to acid extrusion after anoxia in rat hippocampal neurons and that inhibition of this pathway increases the observable contribution of $\mathrm{Na}^{+} / \mathrm{H}^{+}$exchange to acid extrusion at this time (Diarra et al., 1999; Sheldon and Church, 2002) (see also Demaurex et al., 1995). In the present experiments, $100 \mu \mathrm{M}$ $\mathrm{Zn}^{2+}$ failed to influence the increase in $\left[\mathrm{Na}^{+}\right]_{\mathrm{i}}$ during anoxia [i.e., at a time when $\mathrm{Na}^{+} / \mathrm{H}^{+}$exchange is inhibited; normalized $\Delta\left[\mathrm{Na}^{+}\right]_{\mathrm{i} \text { (during) }}$ values in the presence of $100 \mu \mathrm{M} \mathrm{Zn}{ }^{2+}$ were $1.03 \pm 0.18(n=12$; $p=0.38)$ and $1.17 \pm 0.15(n=15 ; p=$ 0.62 ) in 6-10 and 11-14 DIV neurons, respectively]. In contrast, applied immediately after anoxia under $\mathrm{K}^{+}{ }_{\mathrm{o}}$-free conditions, $\mathrm{Zn}^{2+}$ significantly enhanced the increase in $\left[\mathrm{Na}^{+}\right]_{\mathrm{i}}$ (Fig. $7 \mathrm{~B}, \mathrm{C}$ ), lending additional support to the possibility that $\mathrm{Na}^{+} / \mathrm{H}^{+}$exchange contributes to $\mathrm{Na}^{+}$ influx immediately after anoxia. Although $\mathrm{Zn}^{2+}$ can modulate the activities of a variety of ion channels and transport mechanisms (Harrison and Gibbons, 1994), under the conditions used here, anoxiaevoked changes in $\left[\mathrm{Na}^{+}\right]_{\mathrm{i}}$ were unaffected by NMDA or AMPA receptor antagonists or blockers of voltage-activated $\mathrm{Ca}^{2+}$ channels, and the effect of $\mathrm{Zn}^{2+}$ on the increase in $\left[\mathrm{Na}^{+}\right]_{\mathrm{i}}$ after anoxia was observed when $\mathrm{Na}^{+}, \mathrm{K}^{+}$-ATPase activity was already inhibited (cf. Manzerra et al., 2001).

Although the above findings are consistent with an important contribution from $\mathrm{Na}^{+} / \mathrm{H}^{+}$exchange to $\mathrm{Na}^{+}$influx in the period immediately after anoxia, they are limited by the lack of selectivity of harmaline and the other maneuvers used to modulate $\mathrm{Na}^{+} / \mathrm{H}^{+}$exchange activity at this time. Therefore, to further explore the role of $\mathrm{Na}^{+} / \mathrm{H}^{+}$exchange in $\mathrm{Na}^{+}$influx after anoxia, we examined directly the relationship between the changes in $\left[\mathrm{Na}^{+}\right]_{\mathrm{i}}$ and $\mathrm{pH}_{\mathrm{i}}$ evoked by anoxia by measuring $\left[\mathrm{Na}^{+}\right]_{\mathrm{i}}$ and $\mathrm{pH}_{\mathrm{i}}$ concurrently in individual neurons (Sheldon et al., 2004). In neurons coloaded with SBFI and either carboxy SNARF-1 or SNARF$5 \mathrm{~F}, 5 \mathrm{~min}$ anoxia evoked a $16 \pm 2 \mathrm{mM}$ increase in $\left[\mathrm{Na}^{+}\right]_{\mathrm{i}}$ and a $0.37 \pm 0.04 \mathrm{pH}$ unit fall in $\mathrm{pH}_{\mathrm{i}}(n=13$ neurons at $7-10 \mathrm{DIV})$, both of which recovered to near resting values on the return to normoxia (Fig. 8A). Perfusion with $\mathrm{K}^{+}$-free medium for $7 \mathrm{~min}$ immediately after anoxia did not affect the recovery of $\mathrm{pH}_{\mathrm{i}}$ (Fig. 8, compare $A, B)$; however, consistent with changes seen in neurons single-loaded with SBFI (Fig. $5 A$ ), inhibition of $\mathrm{Na}^{+}, \mathrm{K}^{+}$-ATPase
$B$
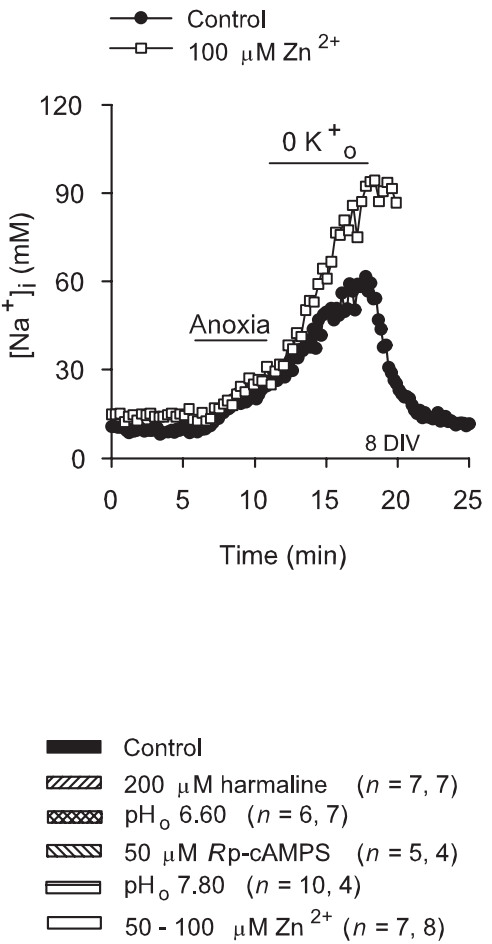

Figure 7. Effects of maneuvers that modulate $\mathrm{Na}^{+} / \mathrm{H}^{+}$exchange activity on increases in $\left[\mathrm{Na}^{+}\right]_{i}$ after anoxia $\left(\mathrm{Na}^{+}, \mathrm{K}^{+}\right.$-

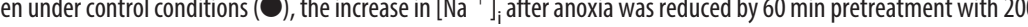
$\mu \mathrm{m}$ harmaline (O). Inset, Rates of $\mathrm{pH}_{\mathrm{i}}$ recovery from internal acid loads imposed under nominally $\mathrm{HCO}_{3}^{-} / \mathrm{CO}_{2}$-free, HEPES-

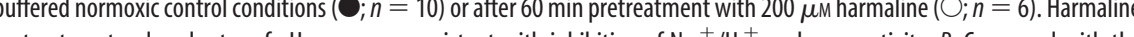
$\left[\mathrm{Na}^{+}\right]_{\mathrm{i}}$ changes evoked by 5 min anoxia under control conditions $(O)$, the increase in $\left[\mathrm{Na}^{+}\right]_{\mathrm{i}}$ after anoxia in age-matched sister neurons was augmented by exposure to $100 \mu \mathrm{m} \mathrm{Zn}{ }^{2+}(\square)$. Exposure to $\mathrm{Zn}^{2+}$ began immediately after the end of 5 min anoxia and continued for the duration of the record shown. C, Summary of the effects of maneuvers that modulate Na ${ }^{+} / \mathrm{H}^{+}$exchange activity on the increase in $\left[\mathrm{Na}^{+}\right]_{\mathrm{i}}$ after anoxia in 6-10 and 11-14 DIV neurons. The asterisk indicates statistical significance $(p<$ 0.05 ) compared with measurements made in age-matched sister neurons under control conditions.

revealed an additional rise in $\left[\mathrm{Na}^{+}\right]_{\mathrm{i}}$ after anoxia of $26 \pm 2 \mathrm{~mm}$ (Fig. 8 B) $(n=49$ neurons at $7-10$ DIV). For both of these experimental series, qualitatively similar changes were observed in neurons maintained for 11-14 DIV (data not shown). If $\mathrm{Na}^{+} / \mathrm{H}^{+}$exchange contributes to increases in $\left[\mathrm{Na}^{+}\right]_{\mathrm{i}}$ and $\mathrm{pH}_{\mathrm{i}}$ in the immediate postanoxic period $\left(\mathrm{Na}^{+}, \mathrm{K}^{+}\right.$-ATPase blocked), both events should be dependent on external $\mathrm{Na}^{+}$, and the rates at which $\mathrm{pH}_{\mathrm{i}}$ and $\left[\mathrm{Na}^{+}\right]_{\mathrm{i}}$ increase should exhibit an inverse dependency on $\mathrm{pH}_{\mathrm{i}}$. Indeed, as illustrated in Figure $8 \mathrm{C}$, the increases in $\mathrm{pH}_{\mathrm{i}}$ and $\left[\mathrm{Na}^{+}\right]_{\mathrm{i}}$ after $5 \mathrm{~min}$ anoxia were abolished under reduced $\left[\mathrm{Na}^{+}\right]_{\mathrm{o}}, \mathrm{NMDG}^{+}$-substituted conditions; when $\left[\mathrm{Na}^{+}\right]_{\mathrm{o}}$ was returned to normal (in the continued absence of $\left.\mathrm{K}^{+}{ }_{\mathrm{o}}\right)$, both $\mathrm{pH}_{\mathrm{i}}$ and $\left[\mathrm{Na}^{+}\right]_{\mathrm{i}}$ rapidly increased $(n=6)$. In addition, when rates at which $\left[\mathrm{Na}^{+}\right]_{\mathrm{i}}$ and $\mathrm{pH}_{\mathrm{i}}$ increased after anoxia were plotted as functions of absolute $\mathrm{pH}_{\mathrm{i}}$ in 7-10 (Fig. 8D) and 11-14 (Fig. 8E) DIV neurons, both parameters were faster at lower $\mathrm{pH}_{\mathrm{i}}$ values.

Finally, we used neurons coloaded with SBFI and a SNARF derivative to examine concurrently the effects on $\left[\mathrm{Na}^{+}\right]_{\mathrm{i}}$ and $\mathrm{pH}_{\mathrm{i}}$ of maneuvers previously found (Diarra et al., 1999; Sheldon and Church, 2002) to limit the activation of $\mathrm{Na}^{+} / \mathrm{H}^{+}$exchange after 
$A$

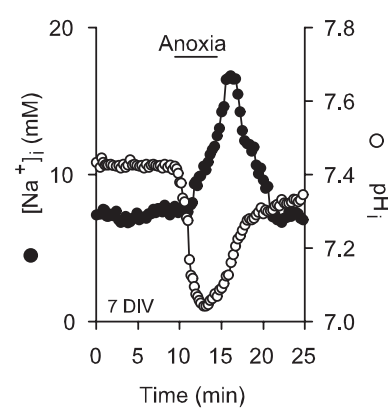

$B$

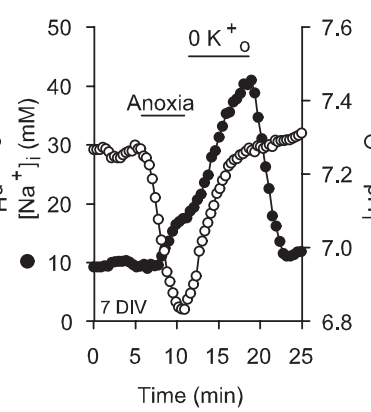

C

$D$

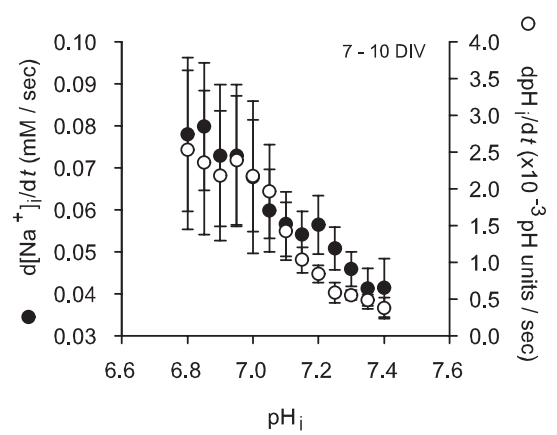

E

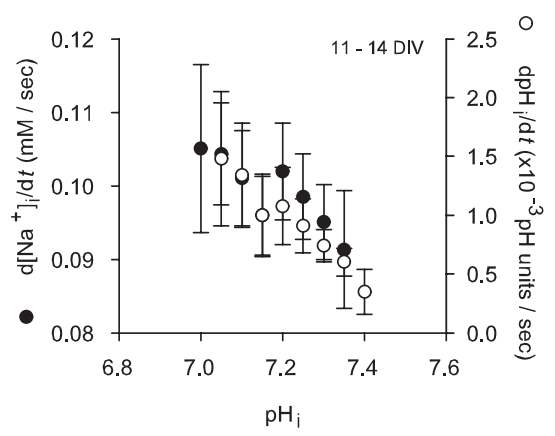

Figure 8. Anoxia-evoked changes in $\mathrm{pH}_{\mathrm{i}}$ and $\left[\mathrm{Na}^{+}\right]_{\mathrm{i}}$ in rat hippocampal neurons coloaded with $\mathrm{SBFl}$ and SNARF-5F. $A$, Anoxia induced an increase in $\left[\mathrm{Na}^{+}\right]_{\mathrm{i}}(\mathbf{O})$ and a fall in $\mathrm{pH}_{\mathrm{i}}(\bigcirc)$, both of which recovered toward resting values after the return to normoxia. $B$, Inhibition of $\mathrm{Na}^{+}, \mathrm{K}^{+}$-ATPase activity (perfusion with $\mathrm{K}^{+}$-free medium) for 7 min after anoxia failed to influence the postanoxic rise in $\mathrm{pH}_{\mathrm{i}}(\boldsymbol{O})$ but revealed an additional increase in $\left[\mathrm{Na}^{+}\right]_{\mathrm{i}}(\boldsymbol{O})$. C, During 5 min anoxia imposed in the presence of external $\mathrm{Na}^{+},\left[\mathrm{Na}^{+}\right]_{\mathrm{i}}(\diamond)$ increased and $\mathrm{pH}_{\mathrm{i}}(\diamond)$ fell. Immediately after anoxia, neurons were superfused with $\mathrm{K}^{+}$- and $\mathrm{Na}^{+}$-free medium $\left(\mathrm{pH}_{0}\right.$ constant at 7.35). Reducing $\mathrm{Na}^{+}{ }_{0}\left(\mathrm{NMDG}^{+}\right.$substitution) for the period indicated by the short bar above the records prevented the increases in $\mathrm{pH}_{\mathrm{i}}$ and $\left[\mathrm{Na}^{+}\right]_{i}$ seen after anoxia in the presence of normal $\mathrm{Na}^{+}{ }_{0}$ (compare with $B$ ). After the return to normal $\mathrm{Na}^{+}{ }_{0}$ (in the continued absence of external $\mathrm{K}^{+}$; arrow), both $\mathrm{pH}_{\mathrm{i}}$ and $\left[\mathrm{Na}^{+}\right]_{\mathrm{i}}$ increased. D, Measured in 20 neurons maintained for 7-10 DIV and coloaded with SBFI and SNARF-5F, rates at which $\left[\mathrm{Na}^{+}\right]_{\mathrm{i}}(\mathbf{O})$ and $\mathrm{pH}_{\mathrm{i}}(\bigcirc)$ increased immediately after anoxia ( $\mathrm{Na}^{+}, \mathrm{K}^{+}$-ATPase inhibited) exhibited an inverse dependence on absolute $\mathrm{pH}_{\mathrm{i}}$ values. Similar results were observed in 11-14 DIV neuronal cultures $(E ; n=10)$. In $D$ and $E$, rates at which $\mathrm{pH}_{\mathrm{i}}$ and $\left[\mathrm{Na}^{+}\right]_{\mathrm{i}}$ increased after anoxia under $\mathrm{K}^{+}{ }_{0}$-free conditions were determined by fitting the $\mathrm{pH}_{\mathrm{i}}$ and $\left[\mathrm{Na}^{+}\right]_{\mathrm{i}}$ records to single exponential functions; the first derivatives of these functions were used to determine rates of $\mathrm{pH}_{i}$ and $\left[\mathrm{Na}^{+}\right]_{\mathrm{i}}$ increase at $0.05 \mathrm{pH}$ unit and $5 \mathrm{~mm}$ intervals, respectively. $\mathrm{The}_{\mathrm{i}}$ values at which rates of $\left[\mathrm{Na}^{+}\right]_{\mathrm{i}}$ increase were measured were determined from obtained curve-fitted parameters.

5 min anoxia. Consistent with findings that $\mathrm{Na}^{+} / \mathrm{H}^{+}$exchange is inhibited during anoxia, pretreatment with harmaline failed to influence the magnitudes of the increase in $\left[\mathrm{Na}^{+}\right]_{i}$ or decrease in $\mathrm{pH}_{\mathrm{i}}$ during anoxia (Fig. $9 \mathrm{~A}$ ); in contrast, harmaline significantly reduced the increases in $\left[\mathrm{Na}^{+}\right]_{\mathrm{i}}$ and $\mathrm{pH}_{\mathrm{i}}$ after anoxia (Fig. $9 B$ ). In further support of a contribution from $\mathrm{Na}^{+} / \mathrm{H}^{+}$exchange to $\mathrm{Na}^{+}$influx (and $\mathrm{H}^{+}$efflux) in the immediate postanoxic period, lowering $\mathrm{pH}_{\mathrm{o}}$ to 6.60 or the application of $50 \mu \mathrm{M} R \mathrm{R}$-cAMPS also reduced the increases in $\left[\mathrm{Na}^{+}\right]_{\mathrm{i}}$ and $\mathrm{pH}_{\mathrm{i}}$ after anoxia (Fig. $9 B$ ). Although PKA regulates $\mathrm{Na}^{+} / \mathrm{Ca}^{2+}$ exchange activity in rat hippocampal neurons under normoxic conditions (Blaustein and Lederer, 1999), the effect of $R \mathrm{p}$-cAMPS to reduce the increase in $\left[\mathrm{Na}^{+}\right]_{\mathrm{i}}$ after anoxia was accompanied by a concomitant reduction in the postanoxic increase in $\mathrm{pH}_{\mathrm{i}}$ and, as shown in Figure 9B, was not mimicked when anoxia was imposed under $\mathrm{Ca}^{2+}{ }_{0}$-free conditions. In the latter experiments (compare the $0 \mathrm{Ca}^{2+}{ }_{\mathrm{o}} \mathrm{ex}-$ periments reported in Table 2), $\mathrm{Ca}^{2+}{ }_{\mathrm{o}}$ was absent before, during, and after anoxia to prevent the rise in $\left[\mathrm{Ca}^{2+}\right]_{\mathrm{i}}$ during anoxia (Diarra et al., 1999; Sheldon and Church, 2002) and inhibit both forward and reverse $\mathrm{Na}^{+} / \mathrm{Ca}^{2+}$ exchange in the immediate postanoxic period. In addition, we have shown previously that this maneuver does not influence anoxiaevoked changes in $\mathrm{pH}_{\mathrm{i}}$ in rat hippocampal neurons (Diarra et al., 1999; Sheldon and Church, 2002).

$\mathrm{HCO}_{3}^{-}$-dependent,

$\mathrm{pH}_{\mathrm{i}}$-regulating mechanisms

The increase in $\left[\mathrm{Na}^{+}\right]_{\mathrm{i}}$ after anoxia $\left(\mathrm{Na}^{+}, \mathrm{K}^{+}\right.$-ATPase inhibited) was consistently greater under $\mathrm{HCO}_{3}^{-}$-containing versus $\mathrm{HCO}_{3}^{-}$-free, HEPES-buffered conditions in 11-14, but not 6-10, DIV neurons (Fig. 10). Consistent with the possibility that $\mathrm{HCO}_{3}^{-}$-dependent transport mechanisms(s) may contribute to $\mathrm{Na}^{+}$influx in the immediate postanoxic period in 11-14 DIV neurons, the augmented increase in $\left[\mathrm{Na}^{+}\right]_{\mathrm{i}}$ observed in the presence of $\mathrm{HCO}_{3}^{-}$ was blocked by $200 \mu \mathrm{M}$ DIDS (Fig. 10). Interestingly, $200 \mu \mathrm{M}$ DIDS also reduced slightly, albeit significantly, the increase in $\left[\mathrm{Na}^{+}\right]_{i}$ observed after anoxia under HEPESbuffered conditions in 11-14 DIV neurons (Fig. $10 \mathrm{~B}$ ), a finding that may reflect residual activity of $\mathrm{HCO}_{3}^{-}$-dependent, $\mathrm{Na}^{+}$-transporting mechanisms in the nominal absence of $\mathrm{HCO}_{3}^{-}$(Wu et al., 1994; Deitmer and Schneider, 1998) or the effects of DIDS on $\mathrm{HCO}_{3}^{-}$-independent processes potentially involved in the neuronal response to anoxia (e.g., free radical release from mitochondria) (Han et al., 2003; Tauskela et al., 2003).

\section{Nonselective cation channels}

As detailed above, $\mathrm{Gd}^{3+}$ significantly reduced $\mathrm{Na}^{+}$influx during anoxia via a mechanism(s) that appeared dependent on the production of ROS. Because ROS production is enhanced after reoxygenation, we applied $\mathrm{Gd}^{3+}$ immediately after anoxia under $\mathrm{K}^{+}{ }_{0}$-free conditions. As illustrated in Figure 11, $30 \mu \mathrm{M} \mathrm{Gd}{ }^{3+}$ significantly reduced the magnitude of the increase in $\left[\mathrm{Na}^{+}\right]_{\mathrm{i}}$ after anoxia in 6-10 DIV neurons; a similar effect was observed in 11-14 DIV neurons, in which $30 \mu \mathrm{M} \mathrm{Gd}{ }^{3+}$ reduced the normalized $\Delta\left[\mathrm{Na}^{+}\right]_{\mathrm{i}(\text { after })}$ value to $0.73 \pm 0.08(n=$ $6 ; p<0.05)$. Similar to findings made during anoxia, the effect of $\mathrm{Gd}^{3+}$ to limit increases in $\left[\mathrm{Na}^{+}\right]_{\mathrm{i}}$ after anoxia was occluded by 2 hr pretreatment with $1 \mathrm{~mm}$ trolox (Fig. $11 \mathrm{~B}$ ). Although $500 \mu \mathrm{M}$ L-NAME was without effect, 15-30 $\mu \mathrm{M} \mathrm{AACOCF}$ s significantly reduced the increase in $\left[\mathrm{Na}^{+}\right]_{\mathrm{i}}$ after anoxia (Fig. $11 \mathrm{~B}$ ), suggesting that ROS generated via the $\mathrm{CPLA}_{2}$-arachidonic acid pathway may play a role in regulating $\mathrm{Na}^{+}$influx in the immediate postanoxic period, possibly by modulating the activity of a $\mathrm{Gd}^{3+}$-sensitive NSCC.

\section{Discussion}

In the present study, we used isolated neurons to characterize pathways independent from glutamate receptor activation that, together with excitotoxic mechanisms (see Introduction), contribute to $\mathrm{Na}^{+}$influx during and after anoxia. Not only were different complements of mechanisms involved during versus after anoxia but also $\mathrm{Na}^{+}$influx during and after anoxia became more pronounced the longer that neurons were maintained in 
culture. The latter observations correspond with previous findings (Jiang et al., 1992) that anoxia-induced falls in $\left[\mathrm{Na}^{+}\right]_{\mathrm{o}}$ are smaller in slices taken from neonatal versus adult rats and suggest that differences in $\mathrm{Na}^{+}$, as well as $\mathrm{Ca}^{2+}$ (Rothman, 1983; Di Loreto and Balestrino, 1997), entry may contribute to the enhanced vulnerability of more phenotypically mature neurons.

We found no evidence to suggest that voltage-activated $\mathrm{Na}^{+}$channels contribute to $\mathrm{Na}^{+}$influx during or after $5 \mathrm{~min}$ anoxia (compare prolonged hypoxia) (Banasiak et al., 2004). Although the relatively small depolarization that occurred during anoxia may have limited the contribution of $\mathrm{Na}^{+}$channels, even in studies in which more severe insults have been imposed and more marked depolarizations have occurred, TTX has failed to limit increases in $\left[\mathrm{Na}^{+}\right]_{\mathrm{i}}$ (Pisani et al., 1998; Calabresi et al., 1999; Chen et al., 1999; Müller and Somjen, 2000). Thus, our findings support suggestions that the protective actions of $\mathrm{Na}^{+}$channel blockers may be mediated presynaptically and that much of the $\mathrm{Na}^{+}$ that enters neurons during anoxia or ischemia must do so through a TTXinsensitive mechanism(s) (Kimura et al., 1998; Müller and Somjen, 2000).

Although $\mathrm{Na}^{+} / \mathrm{K}^{+} / 2 \mathrm{Cl}^{-}$cotransport did not play a role in regulating resting $\left[\mathrm{Na}^{+}\right]_{\mathrm{i}}$ (see also Rose and Ransom, 1997), it contributed to $\mathrm{Na}^{+}$influx during anoxia in neurons expected to express significant levels of functional transporters (i.e., neurons $\geq 11$ DIV) (Sun and Murali, 1999) (see also Plotkin et al., 1997). Similarly, $\mathrm{Na}^{+} / \mathrm{K}^{+} / 2 \mathrm{Cl}^{-}$cotransport contributes to $\mathrm{Na}^{+}{ }_{\mathrm{i}}$ accumulation induced by metabolic inhibition in astrocytes (Lenart et al., 2004) and cardiac myocytes (Anderson et al., 1996). In contrast, bumetanide failed to affect $\mathrm{Na}^{+}$influx after anoxia in 6-10 and 11-14 DIV neurons. Although the basis for the differential contribution of $\mathrm{Na}^{+} / \mathrm{K}^{+} / 2 \mathrm{Cl}^{-}$cotransport to $\mathrm{Na}^{+}$influx during versus after anoxia in 11-14 DIV neurons remains unknown, inward $\mathrm{Na}^{+} /$ $\mathrm{K}^{+} / 2 \mathrm{Cl}^{-}$cotransport after anoxia may be limited by the high $\left[\mathrm{Na}^{+}\right]_{\mathrm{i}}$ and, presumably, $\left[\mathrm{Cl}^{-}\right]_{\mathrm{i}}$ seen at this time as well as anoxia-induced changes in the activities of second-messenger systems that in turn regulate the activity of the transport mechanism and that are themselves developmentally regulated (Durkin et al., 1997; Flatman, 2002; Lenart et al., 2004). Together, our observations parallel findings that bumetanide reduces infarct size when applied during but not after ischemia (Yan et al., 2003) and suggest that the protective effects of bumetanide may in part reflect a reduction in $\mathrm{Na}^{+}$influx during the insult.

In contrast to $\mathrm{Na}^{+} / \mathrm{K}^{+} / 2 \mathrm{Cl}^{-}$cotransport, $\mathrm{Na}^{+} / \mathrm{Ca}^{2+} \mathrm{ex}-$ under each test condition.

$B$
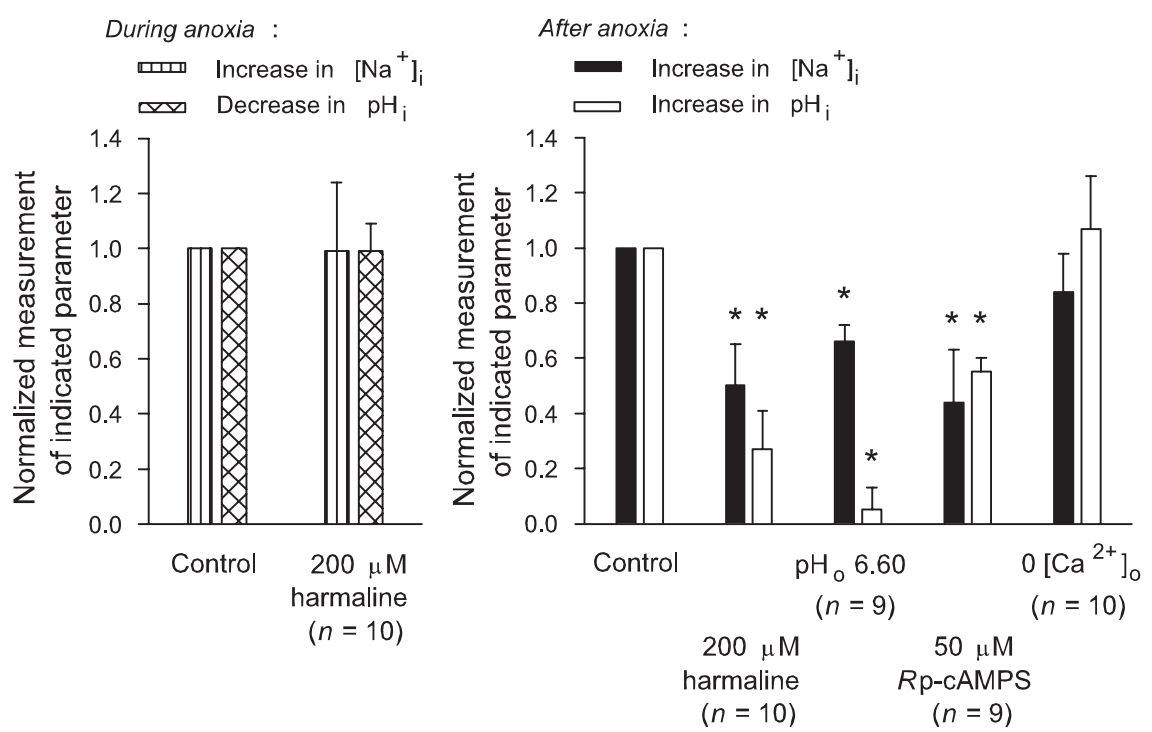

Figure 9. The influence of maneuvers that inhibit $\mathrm{Na}^{+} / \mathrm{H}^{+}$exchange activity on anoxia-evoked changes in $\left[\mathrm{Na}^{+}\right]_{\mathrm{i}}$ and $\mathrm{pH}_{\mathrm{i}}$ measured concurrently in neurons coloaded with SBFl and either carboxy SNARF-1 or SNARF-5F. Measurements of the changes in $\left[\mathrm{Na}^{+}\right]_{\mathrm{i}}$ and $\mathrm{pH}_{\mathrm{i}}$ observed during $(A)$ and after $(B)$ anoxia under the test conditions indicated on the figure were normalized to corresponding measurements made in experiments performed on age-matched sister neurons (7-10 DIV) under control conditions. Statistical comparisons were performed by comparing absolute measurements of anoxia-evoked changes in $\left[\mathrm{Na}^{+}\right]_{\mathrm{i}}$ and $\mathrm{pH}_{\mathrm{i}}$ made under a given test condition with corresponding measurements made in age-matched sister neurons under control conditions. The asterisk indicates statistical significance $(p<0.05)$ compared with measurements made in age-matched sister neurons under control conditions. The numbers in parentheses indicate the number of neurons from which data were obtained

$A$

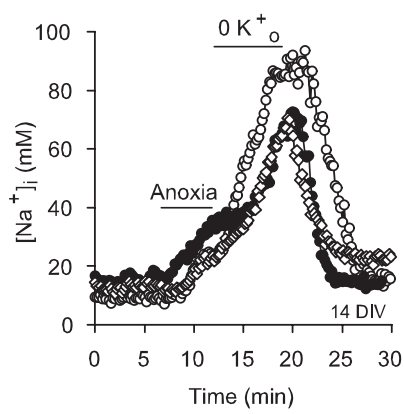

Figure 10. Contribution of $\mathrm{HCO}_{3}^{-}$-dependent mechanisms to increases in $\left[\mathrm{Na}^{+}\right]_{\mathrm{i}}$ after anoxia $\left(\mathrm{Na}^{+}, \mathrm{K}^{+}\right.$-ATPase inhibited). $A$, Under HEPES-buffered $(\bigcirc)$ or $\mathrm{HCO}_{3}^{-} / \mathrm{CO}_{2}$-buffered $(\bigcirc)$ conditions, neurons were exposed to 5 min anoxia, followed by 7 min perfusion with $\mathrm{K}^{+}$-free medium. The augmented increase in $\left[\mathrm{Na}^{+}\right]_{i}$ observed after anoxia in the presence of $\mathrm{HCO}_{3}^{-}$was inhibited by $200 \mu \mathrm{m} \operatorname{DIDS}(\diamond)$, which was added at the start of anoxia and remained present throughout the rest of the record shown. $B$, Summary of the effects of external buffering conditions and DIDS on the increase in $\left[\mathrm{Na}^{+}\right]_{i}$ after anoxia in $6-10$ and $11-14$ DIV neurons. In contrast to results obtained in 6-10 DIV neurons, the increase in $\left[\mathrm{Na}^{+}\right]_{i}$ after anoxia in $11-14$ DIV neurons was enhanced in the presence of $\mathrm{HCO}_{3}^{-}$and, under this condition, DIDS significantly reduced $\left({ }^{\dagger} p<0.05\right)$ the magnitude of the rise in $\left[\mathrm{Na}^{+}\right]_{\mathrm{i}}$ to a value not significantly different $(p=0.66)$ to that seen under $\mathrm{HCO}_{3}^{-}$-free, HEPES-buffered conditions. In 11-14 DIV neurons, DIDS also significantly $\left({ }^{*} p<0.05\right)$ reduced the increase in $\left[\mathrm{Na}^{+}\right]_{\mathrm{i}}$ observed after anoxia under nominally $\mathrm{HCO}_{3}^{-}$-free, HEPES-buffered conditions. There was no significant difference $(p=0.15)$ between the increases in $\left[\mathrm{Na}^{+}\right]_{i}$ after anoxia observed in the presence of DIDS under $\mathrm{HCO}_{3}^{-}$-containing versus nominally $\mathrm{HCO}_{3}^{-}$-free conditions. change, $\mathrm{Na}^{+} / \mathrm{H}^{+}$exchange, and the $\mathrm{HCO}_{3}^{-}$-dependent mechanism(s) did not contribute to $\mathrm{Na}^{+}$influx during anoxia. These observations are consistent with findings that $\mathrm{Na}^{+} / \mathrm{Ca}^{2+}$ exchange does not contribute to $\left[\mathrm{Na}^{+}\right]_{\mathrm{i}}$ and/or $\left[\mathrm{Ca}^{2+}\right]_{\mathrm{i}}$ changes during metabolic inhibition in rat neocortical (Pisani et al., 1998) or cerebellar granule (Chen et al., 1999) neurons and that $\mathrm{Na}^{+} / \mathrm{H}^{+}$exchange and $\mathrm{Na}^{+}$-dependent $\mathrm{Cl}^{-} / \mathrm{HCO}_{3}^{-}$exchange do not contribute to $\mathrm{pH}_{\mathrm{i}}$ changes during anoxia in rat hippocam- 
$A$

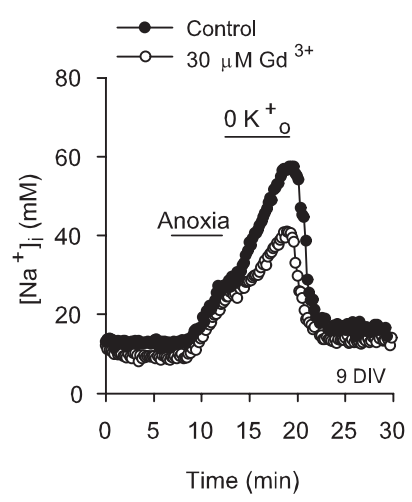

$B$

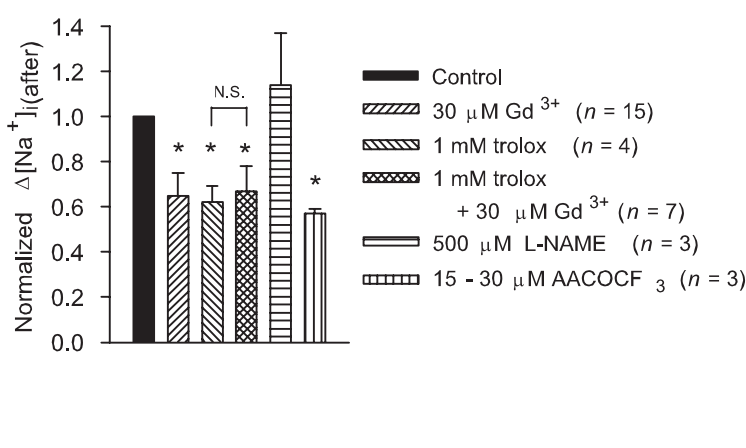

Figure 11. Effects of $\mathrm{Gd}^{3+}$ on increases in $\left[\mathrm{Na}^{+}\right]_{\mathrm{i}}$ after anoxia ( $\mathrm{Na}^{+}, \mathrm{K}^{+}$-ATPase inhibited). A, Exposure to $30 \mu \mathrm{m} \mathrm{Gd}{ }^{3+}$ immediately after anoxia under $\mathrm{K}^{+}{ }_{0}$-free conditions $(O)$ reduced the increase in $\left[\mathrm{Na}^{+}\right]_{\mathrm{i}}$ after anoxia compared with that observed in age-matched sister neurons under control conditions $(\boldsymbol{O})$. B, Summary of the effects of the test treatments indicated on the figure on the increases in $\left[\mathrm{Na}^{+}\right]_{\mathrm{i}}$ after anoxia in 6-10 DIV neuronal cultures. Neurons were pretreated with trolox for $2 \mathrm{hr}$ before the start of anoxia and with L-NAME or AACOCF for $20 \mathrm{~min}$ before the start of anoxia. The asterisk indicates statistical significance $(p<0.05)$ compared with measurements made in age-matched sister neurons under control conditions. N.S., No statistically significant difference $(p=0.67)$ between the increase in $\left[\mathrm{Na}^{+}\right]_{\mathrm{i}}$ observed after anoxia in the absence and presence of $\mathrm{Gd}^{3+}$ in neurons pretreated with trolox.

pal neurons (Diarra et al., 1999; Sheldon and Church, 2004). The lack of involvement of $\mathrm{Na}^{+} / \mathrm{Ca}^{2+}, \mathrm{Na}^{+} / \mathrm{H}^{+}$, and $\mathrm{Na}^{+}-$ dependent $\mathrm{Cl}^{-} / \mathrm{HCO}_{3}^{-}$exchange in $\mathrm{Na}^{+}, \mathrm{Ca}^{2+}$ and/or $\mathrm{pH}_{\mathrm{i}}$ fluxes during anoxia contrasts with their activation by glutamate or NMDA (Hartley and Dubinsky, 1993; Canzoniero et al., 1996; Yu and Choi, 1997) and may reflect the inhibitory effects of reductions in internal ATP and/or phosphatidylinositol 4,5bisphosphate levels on the activities of each of these mechanisms (Blaustein and Lederer, 1999; Romero et al., 2004; Sheldon and Church, 2004).

Counter to findings made during anoxia, $\mathrm{Na}^{+} / \mathrm{Ca}^{2+}$ exchange, $\mathrm{Na}^{+} / \mathrm{H}^{+}$exchange, and the $\mathrm{HCO}_{3}^{-}$-dependent mechanism(s) contributed to $\mathrm{Na}^{+}$fluxes immediately after anoxia. With regard to $\mathrm{Na}^{+} / \mathrm{Ca}^{2+}$ exchange, measurements of $\left[\mathrm{Na}^{+}\right]_{\mathrm{i}}$ (present study) and $\left[\mathrm{Ca}^{2+}\right]_{\mathrm{i}}$ (Diarra et al., 1999) suggest that the reversal potential of $3 \mathrm{Na}^{+} / 1 \mathrm{Ca}^{2+}$ exchange at the return to normoxia is approximately $-90 \mathrm{mV}$ [i.e., more negative than the membrane potential at the end of $5 \mathrm{~min}$ anoxia (approximately $-40 \mathrm{mV}$ )]. Also consistent with a contribution from reverse $\mathrm{Na}^{+} / \mathrm{Ca}^{2+}$ exchange to $\mathrm{Na}^{+}$efflux after anoxia, $1 \mu \mathrm{M} \mathrm{KB}-\mathrm{R} 7943$ enhanced the increase in $\left[\mathrm{Na}^{+}\right]_{\mathrm{i}}$ at this time. However, when KB-R7943 was applied at $10 \mu \mathrm{M}$, a concentration that inhibits forward and reverse $\mathrm{Na}^{+} / \mathrm{Ca}^{2+}$ exchange, the increase in $\left[\mathrm{Na}^{+}\right]_{\mathrm{i}}$ after anoxia was reduced, an effect that was mimicked by bepridil. These observations are consistent with the possibility (Yu and Choi, 1997) that forward and reverse $\mathrm{Na}^{+} / \mathrm{Ca}^{2+}$ exchange can take place concomitantly in the same cell, perhaps reflecting differences in the distribution of $\mathrm{Ca}^{2+}$ and/or $\mathrm{Na}^{+}$in submembrane microdomains. Simultaneous measurements of $\left[\mathrm{Na}^{+}\right]_{\mathrm{i}}$ and $\left[\mathrm{Ca}^{2+}\right]_{\mathrm{i}}$ with appropriate spatial resolution in combination with the control of membrane potential will be required to substantiate or refute this possibility. The present results also extend previous findings, made on the basis of $\mathrm{pH}_{\mathrm{i}}$ measurements, that $\mathrm{Na}^{+} / \mathrm{H}^{+}$exchange in rat hippocampal neurons is activated immediately after anoxia (Diarra et al., 1999; Sheldon and Church, 2002) (see also Vornov et al., 1996; Kintner et al., 2004) and indicate that $\mathrm{Na}^{+} / \mathrm{H}^{+}$exchange is an important determinant of $\mathrm{Na}^{+}$influx at this time. In cardiac myocytes, activation of $\mathrm{Na}^{+} / \mathrm{H}^{+}$exchange immediately after anoxia or ischemia pro- motes reverse $\mathrm{Na}^{+} / \mathrm{Ca}^{2+}$ exchange and $\mathrm{Ca}^{2+}{ }_{\mathrm{i}}$ loading (Avkiran, 2001). Not only might a similar sequence of events occur in rat hippocampal neurons but also the rapid rise in $\mathrm{pH}_{\mathrm{i}}$ consequent on the activation of $\mathrm{Na}^{+} / \mathrm{H}^{+}$exchange after anoxia stimulates $\mathrm{PLA}_{2}$ (Phillis and O'Regan, 2004) that in turn may promote additional $\mathrm{Na}^{+}$entry via the production of ROS (see below). Our findings support the possibility (Vornov et al., 1996) that the neuroprotective effects of $\mathrm{Na}^{+} / \mathrm{H}^{+}$exchange inhibitors are mediated, not during anoxia but by limiting $\mathrm{Na}^{+}$influx and/or $\mathrm{H}^{+}$efflux in the immediate postanoxic period, and parallel reports that $\mathrm{Na}^{+} / \mathrm{H}^{+}$exchange inhibitors are neuroprotective in vivo only when administered before reperfusion (Phillis et al., 1999; Horikawa et al., 2001a,b). Finally, although an $\mathrm{HCO}_{3}^{-}-$ dependent mechanism(s) contributed to $\mathrm{Na}^{+}$influx after anoxia in 11-14, but not $6-10$, DIV neurons, its identity remains unclear. The sensitivity of the mechanism(s) to DIDS and the inability of TTX and lidocaine to inhibit $\mathrm{Na}^{+}$influx after anoxia appear to exclude an effect of $\mathrm{HCO}_{3}^{-}$ions on $\mathrm{Na}^{+}$currents (Bruehl and Witte, 2003). In addition, although $\mathrm{Na}^{+}$-dependent $\mathrm{Cl}^{-} / \mathrm{HCO}_{3}^{-}$exchange and electroneutral or inward electrogenic $\mathrm{Na}^{+} / \mathrm{HCO}_{3}^{-}$cotransport are sensitive to DIDS, mediate $\mathrm{Na}^{+}$influx, and are developmentally upregulated (Douglas et al., 2001; Giffard et al., 2003; Romero et al., 2004), they act to increase $\mathrm{pH}_{\mathrm{i}}$, which is at odds with previous findings that $\mathrm{HCO}_{3}^{-}$limits $\mathrm{H}^{+}$efflux from rat hippocampal neurons after 5 min anoxia (Diarra et al., 1999; Sheldon and Church, 2002). Rather, the $\mathrm{HCO}_{3}^{-}$-induced increase in $\mathrm{Na}^{+}$influx at reoxygenation may reflect the net effect of the activities of multiple $\mathrm{Na}^{+}{ }_{-}$ and $\mathrm{HCO}_{3}^{-}$-dependent, DIDS-sensitive transport mechanisms, including outward electrogenic $\mathrm{Na}^{+} / \mathrm{HCO}_{3}^{-}$cotransport. Additional experiments will be required to establish precisely which mechanisms are involved and to assess whether their inhibition contributes to the neuroprotective properties of DIDS (Tauskela et al., 2003).

Finally, $\mathrm{Gd}^{3+}$ attenuated $\mathrm{Na}^{+}$influx during and after anoxia. Although the effects of $\mathrm{Gd}^{3+}$ could not be ascribed to inhibition of AMPA/kainate receptors or $\mathrm{Ca}^{2+}{ }_{\mathrm{i}}$-activated NSCCs, they were occluded by pretreatment with trolox, suggesting that the $\mathrm{Gd}^{3+}$. sensitive pathway mediating $\mathrm{Na}^{+}$influx may be activated by ROS. Although $\mathrm{Gd}^{3+}$ also limits $\mathrm{Ca}^{2+}$ influx induced by $5 \mathrm{~min}$ anoxia under conditions identical to those used here (A. Diarra and J. Church, unpublished observations) (see also Diarra et al., 1999), the pathway involved in the production of ROS in the present experiments differs from that implicated in the activation of the $\mathrm{Gd}^{3+}$-sensitive NSCC that contributes to $\mathrm{Ca}^{2+}$ influx during prolonged ( $>30 \mathrm{~min}$ ) $\mathrm{O}_{2}$ - glucose deprivation in murine cortical neurons (Aarts et al., 2003) in that it does not appear to depend on NOS. Although additional experiments are required to identify the pathway(s) involved in the generation of ROS during anoxia (including possible contributions from NO generated via NOS-independent pathways), $\mathrm{cPLA}_{2}$ may be involved after anoxia [compare rat cerebellar granule neurons in which $\mathrm{PLA}_{2}$, acting through the production of ROS, is an important determinant of $\mathrm{Na}^{+}$influx during metabolic inhibition (Chen et al., 1999)]. 
In summary, $\mathrm{Na}^{+}$influx occurs during and immediately after a short period of anoxia in rat hippocampal neurons. Sodium influx during anoxia may contribute to acute neuronal injury, whereas $\mathrm{Na}^{+}$influx after anoxia may be a factor in the progression of injury that occurs in the reperfusion period. Our findings emphasize that multiple pathways, the relative contributions of which vary during versus immediately after anoxia, contribute to $\mathrm{Na}^{+}$influx induced by anoxia in rat hippocampal neurons and suggest that combination therapies may prove more useful than strategies directed toward individual pathways in reducing the potentially detrimental $\mathrm{Na}^{+}$influx that occurs in response to metabolic inhibition.

\section{References}

Aarts M, Iihara K, Wei W-L, Xiong K-G, Arundine M, Cerwinski W, MacDonald JF, Tymianski M (2003) A key role for TRPM7 channels in anoxic neuronal death. Cell 115:863-877.

Anderson SE, Dickinson CZ, Liu H, Cala PM (1996) Effects of Na-K-2Cl cotransport inhibition on myocardial $\mathrm{Na}$ and $\mathrm{Ca}$ during ischemia and reperfusion. Am J Physiol 270:C608-C618.

Attaphitaya S, Park K, Melvin JE (1999) Molecular cloning and functional expression of a rat $\mathrm{Na}^{+} / \mathrm{H}^{+}$exchanger (NHE5) highly expressed in brain. J Biol Chem 274:4383-4388.

Avkiran M (2001) Protection of the ischemic myocardium by $\mathrm{Na}^{+} / \mathrm{H}^{+}$exchange inhibitors: potential mechanisms of action. Basic Res Cardiol 96:306-311.

Balestrino M, Lensman M, Parodi M, Perasso L, Rebaudo R, Melani R, Polenov S, Cupello A (2002) Role of creatine and phosphocreatine in neuronal protection from anoxic and ischemic damage. Amino Acids 23:221-229.

Banasiak KJ, Burenkova O, Haddad GG (2004) Activation of voltagesensitive sodium channels during oxygen deprivation leads to apoptotic neuronal death. Neuroscience 126:31-44.

Barros LF, Stutzin A, Calixto A, Catalán M, Castro J, Hetz C, Hermosilla T (2001) Nonselective cation channels as effectors of free radical-induced rat liver cell necrosis. Hepatology 33:114-122.

Baxter KA, Church J (1996) Characterization of acid extrusion mechanisms in cultured fetal rat hippocampal neurons. J Physiol (Lond) 23:457-470.

Blaustein MP, Lederer WJ (1999) Sodium/calcium exchange: its physiological implications. Physiol Rev 79:763-854.

Boland LM, Brown TA, Dingledine R (1991) Gadolinium block of calcium channels: influence of bicarbonate. Brain Res 563:142-150.

Breder J, Sabelhau CF, Opitz T, Reymann KG, Schröder UH (2000) Inhibition of different pathways influencing $\mathrm{Na}^{+}$homeostasis protects organotypic hippocampal slice cultures from hypoxic/hypoglycemic injury. Neuropharmacology 39:1779-1787.

Brookes PS, Land JM, Clark JB, Heales SJR (1998) Peroxynitrite and brain mitochondria: evidence for increased proton leak. J Neurochem 70:2195-2202.

Bruehl G, Witte OW (2003) Relation between bicarbonate concentration and voltage dependence of sodium currents in freshly isolated CA1 neurons of the rat. J Neurophysiol 89:2489-2498.

Calabresi P, Marfia GA, Centonze D, Pisani A, Bernardi G (1999) Sodium influx plays a major role in membrane depolarization induced by oxygen and glucose deprivation in rat striatal spiny neurons. Stroke 30:171-178.

Caldwell RA, Clemo HF, Baumgarten CM (1998) Using gadolinium to identify stretch-activated channels: technical considerations. Am J Physiol 275:C619-C621.

Canzoniero LM, Sensi SL, Choi DW (1996) Recovery from NMDA-induced intracellular acidification is delayed and dependent on extracellular bicarbonate. Am J Physiol 270:C593-C599.

Carmeliet E (1999) Cardiac ionic currents and acute ischemia: from channels to arrhythmias. Physiol Rev 79:917-1017.

Chen W-H, Chu K-C, Wu S-J, Wu J-C, Shui H-A, Wu M-L (1999) Early metabolic inhibition-induced intracellular sodium and calcium increase in rat cerebellar granule cells. J Physiol (Lond) 515:133-149.

Chidekel AS, Friedman JE, Haddad GG (1997) Anoxia-induced neuronal injury: role of $\mathrm{Na}^{+}$entry and $\mathrm{Na}^{+}$-dependent transport. Exp Neurol 146:403-413.

Chow HS, Lynch III JJ, Rose K, Chow DW (1994) Trolox attenuates cortical neuronal injury induced by iron, ultraviolet light, glucose deprivation, or AMPA. Brain Res 639:102-108.

Chinopoulos C, Tretter L, Rozsa A, Adam-Vizi V (2000) Exacerbated responses to oxidative stress by an $\mathrm{Na}^{+}$load in isolated nerve terminals: the role of ATP depletion and rise of $\left[\mathrm{Ca}^{2+}\right]_{\mathrm{i}}$. J Neurosci 20:2094-2103.

Church J, Fletcher EJ, Abdel-Hamid K, MacDonald JF (1994) Loperamide blocks high-voltage-activated calcium channels and N-methyl-Daspartate-evoked responses in rat and mouse cultured hippocampal pyramidal neurons. Mol Pharmacol 45:747-757.

Cooper DMF, Schell MJ, Thorn P, Irvine RF (1998) Regulation of adenylyl cyclase by membrane potential. J Biol Chem 273:27703-27707.

Czyż A, Kiedrowski L (2003) Inhibition of plasmalemmal $\mathrm{Na}^{+} / \mathrm{Ca}^{2+} \mathrm{ex}-$ change by mitochondrial $\mathrm{Na}^{+} / \mathrm{Ca}^{2+}$ exchange inhibitor 7-chloro-5-(2chlorophenyl)-1,5-dihydro-4,1-benzothiazepin-2(3H)-one (CGP-37157) in cerebellar granule cells. Biochem Pharmacol 66:2409-2411.

Czyż A, Baranauskas G, Kiedrowski L (2002) Instrumental role of $\mathrm{Na}^{+}$in NMDA excitotoxicity in glucose-deprived and depolarized cerebellar granule cells. J Neurochem 81:379-389.

Deecher DC, Teitler M, Soderlund DM, Bornmann WG, Kuehne ME, Glick SD (1992) Mechanisms of action of ibogaine and harmaline congeners based on radioligand binding studies. Brain Res 571:242-247.

Deitmer JW, Schneider H-P (1998) Acid/base transport across the leech giant glial cell membrane at low external bicarbonate concentration. J Physiol (Lond) 512:459-469.

Demaurex N, Orlowski J, Brisseau G, Woodside M, Grinstein S (1995) The mammalian $\mathrm{Na}^{+} / \mathrm{H}^{+}$antiporters NHE-1, NHE-2 and NHE-3 are electroneutral and voltage independent, but can couple to an $\mathrm{H}^{+}$conductance. J Gen Physiol 106:85-111.

Di Loreto S, Balestrino M (1997) Development of vulnerability to hypoxic damage in in vitro hippocampal neurons. Int J Dev Neurosci 15:225-230.

Diarra A, Sheldon C, Brett CL, Baimbridge KG, Church J (1999) Anoxiaevoked intracellular $\mathrm{pH}$ and $\mathrm{Ca}^{2+}$ concentration changes in cultured postnatal rat hippocampal neurons. Neuroscience 93:1003-1016.

Diarra A, Sheldon C, Church J (2001) In situ calibration and $\left[\mathrm{H}^{+}\right]$sensitivity of the fluorescent $\mathrm{Na}^{+}$indicator, SBFI. Am J Physiol 280:C1623-C1633.

Douglas RM, Schmitt BM, Xia Y, Bevensee MO, Biemesderfer D, Boron WF, Haddad GG (2001) Sodium-hydrogen exchangers and sodiumbicarbonate co-transporters: ontogeny of protein expression in the rat brain. Neuroscience 102:217-228.

Durkin JP, Tremblay R, Chakravarthy B, Mealing G, Morley P, Small D, Song D (1997) Evidence that the early loss of membrane protein kinase C is a necessary step in the excitatory amino acid-induced death of primary cortical neurons. J Neurochem 68:1400-1412.

Ekholm A, Katsura K, Kristián T, Liu M, Folbergrová J, Siesjö BK (1993) Coupling of cellular energy state and ion homeostasis during recovery following brain ischemia. Brain Res 604:185-191.

Erecińska M, Silver IA (2001) Tissue oxygen tension and brain sensitivity to hypoxia. Respir Physiol 128:263-276.

Flatman PW (2002) Regulation of Na-K-2Cl cotransport by phosphorylation and protein-protein interactions. Biochim Biophys Acta 1566:140-151.

Friedman JE, Haddad GG (1994) Anoxia induces an increase in intracellular sodium in rat central neurons in vitro. Brain Res 663:329-334.

Giffard RG, Lee Y-S, Ouyang YB, Murphy SL, Monyer H (2003) Two variants of the rat brain sodium-driven chloride bicarbonate exchanger (NCBE): developmental expression and addition of a PDZ motif. Eur J Neurosci 18:2935-2945.

Goldberg MP, Choi DW (1993) Combined oxygen and glucose deprivation in cortical cell culture: calcium-dependent and calcium-independent mechanisms of neuronal injury. J Neurosci 13:3510-3524.

Haddad GG, Jiang C (1993) Mechanisms of anoxia-induced depolarization in brainstem neurons: in vitro current and voltage clamp studies in the adult rat. Brain Res 625:261-268.

Han D, Antunes F, Canali R, Rettori D, Cadenas E (2003) Voltagedependent anion channels control the release of the superoxide anion from mitochondria to cytosol. J Biol Chem 278:5557-5563.

Harrison NL, Gibbons SJ (1994) $\mathrm{Zn}^{2+}$ : an endogenous modulator of ligand- and voltage-gated ion channels. Neuropharmacology 33:935-952.

Hartley Z, Dubinsky JM (1993) Changes in intracellular pH associated with glutamate excitotoxicity. J Neurosci 13:4690-4699.

Hayasaki-Kajiwara Y, Kitano Y, Iwasaki T, Shimamura T, Naya N, Iwaki K, Nakajima M (1999) $\mathrm{Na}^{+}$influx via $\mathrm{Na}^{+} / \mathrm{H}^{+}$exchange activates protein 
kinase $\mathrm{C}$ isozymes $\delta$ and $\epsilon$ in cultured neonatal cardiac myocytes. J Mol Cell Cardiol 31:1559-1572.

Horikawa N, Kuribayashi Y, Matsui K, Ohashi N (2001a) Relationship between the neuroprotective effect of $\mathrm{Na}^{+} / \mathrm{H}^{+}$exchange inhibitor SM20220 and the timing of its administration in a transient middle cerebral artery occlusion model of rats. Biol Pharm Bull 24:767-771.

Horikawa N, Nishioka M, Itoh N, Kuribayashi Y, Matsui K, Ohashi N (2001b) The $\mathrm{Na}^{+} / \mathrm{H}^{+}$exchanger SM-20220 attenuates ischemic injury in in vitro and in vivo models. Pharmacology 63:76-81.

Jiang C, Aqulian S, Haddad GG (1992) $\mathrm{Cl}^{-}$and $\mathrm{Na}^{+}$homeostasis during anoxia in rat hypoglossal neurons: intracellular and extracellular in vitro studies. J Physiol (Lond) 448:697-708.

Kim YK, Park YS, Lee SH (1988) Effect of harmaline on organic ion transport in rabbit renal cortical slices. Arch Int Pharmacodyn Ther 294:259-272.

Kimura M, Sawada K, Miyagawa T, Kuwada M, Katayama K, Nishizawa Y (1998) Role of glutamate receptors and voltage-dependent calcium and sodium channels in the extracellular glutamate/aspartate accumulation and subsequent neuronal injury induced by oxygen/glucose deprivation in cultured hippocampal neurons. J Pharmacol Exp Ther 285:178-185.

Kintner DB, Su G, Lenart BA, Ballard AJ, Meyer JW, Ng LL, Shull GE, Sun D (2004) Increased tolerance to oxygen and glucose deprivation in astrocytes from $\mathrm{Na}^{+} / \mathrm{H}^{+}$exchanger isoform 1 null mice. Am J Physiol 287:C12-C21.

Lei S, MacDonald JF (2001) Gadolinium reduces AMPA receptor desensitization and deactivation in hippocampal neurons. J Neurophysiol 86:173-182.

Lenart B, Kintner DB, Shull GE, Sun D (2004) Na-K-Cl cotransportermediated intracellular $\mathrm{Na}^{+}$accumulation affects $\mathrm{Ca}^{2+}$ signaling in astrocytes in an in vitro ischemic model. J Neurosci 24:9585-9597.

Lipton P (1999) Ischemic cell death in brain neurons. Physiol Rev 79:1431-1568.

LoPachin RM, Gaughan CL, Lehning EJ, Weber ML, Taylor CP (2001) Effects of ion channel blockage on the distribution of $\mathrm{Na}, \mathrm{K}, \mathrm{Ca}$ and other elements in oxygen-glucose deprived CA1 hippocampal neurons. Neuroscience 103:971-983.

Manzerra P, Behrens MM, Canzoniero LMT, Wang XQ, Heidinger V, Ichinose T, Yu SP, Choi DW (2001) Zinc induces a Src family kinasemediated up-regulation of NMDA receptor activity and excitotoxicity. Proc Natl Acad Sci USA 98:11055-11061.

Martinez-Sánchez M, Striggow F, Schröder UH, Kahlert S, Reymann KG, Reiser G (2004) $\mathrm{Na}^{+}$and $\mathrm{Ca}^{2+}$ homeostasis pathways, cell death and protection after oxygen-glucose deprivation in organotypic hippocampal slice cultures. Neuroscience 128:729-740.

Müller M, Somjen GG (2000) $\mathrm{Na}^{+}$and $\mathrm{K}^{+}$concentrations, extra- and intracellular voltages, and the effect of TTX in hypoxic rat hippocampal slices. J Neurophysiol 83:735-745.

Orlowski J (1993) Heterologous expression and functional properties of amiloride high affinity (NHE-1) and low affinity (NHE-3) isoforms of the rat $\mathrm{Na} / \mathrm{H}$ exchanger. J Biol Chem 268:16369-16377.

Payne JA, Rivera C, Voipio J, Kaila K (2003) Cation-chloride cotransporters in neuronal communication, development and trauma. Trends Neurosci 26:199-206.

Phillis JW, O’Regan MH (2004) A potentially critical role of phospholipases in central nervous system ischemic, traumatic and neurodegenerative disorders. Brain Res Rev 44:13-47.

Phillis JW, Estevez AY, Guyot LL, O’Regan MH (1999) 5-(N-ethyl-Nisopropyl)-amiloride, an $\mathrm{Na}^{+}-\mathrm{H}^{+}$exchange inhibitor, protects gerbil hippocampal neurons from ischemic injury. Brain Res 839:199-202.

Pisani A, Calabresi P, Tozzi A, Bernardi G, Knopfel T (1998) Early sodium elevations induced by combined oxygen and glucose deprivation in pyramidal cortical neurons. Eur J Neurosci 10:3572-3584.

Plotkin MD, Snyder EY, Hebert SC, Delpire E (1997) Expression of the $\mathrm{Na}-\mathrm{K}-2 \mathrm{Cl}$ cotransporter is developmentally regulated in postnatal rat brains: a possible mechanism underlying GABA's excitatory role in immature brain. J Neurobiol 33:781-795.

Raley-Susman KM, Cragoe Jr EJ, Sapolsky RM, Kopito RR (1991) Regulation of intracellular $\mathrm{pH}$ in cultured hippocampal neurons by an amiloride-insensitive $\mathrm{Na}^{+} / \mathrm{H}^{+}$exchanger. J Biol Chem 266:2739-2745.
Roettger V, Lipton P (1996) Mechanism of glutamate release from rat hippocampal slices during in vitro ischemia. Neuroscience 75:677-685.

Romero MF, Fulton CM, Boron WF (2004) The SLC4 family of $\mathrm{HCO}_{3}$ transporters. Pflügers Arch 447:495-509.

Rose CR, Ransom BR (1997) Regulation of intracellular sodium in cultured rat hippocampal neurones. J Physiol (Lond) 499:573-587.

Rothman SM (1983) Synaptic activity mediates death of hypoxic neurons. Science 220:536-537.

Russell JM (2000) Sodium-potassium-chloride cotransport. Physiol Rev 80:211-276.

Schwiening CJ, Boron WF (1994) Regulation of intracellular $\mathrm{pH}$ in pyramidal neurones from the rat hippocampus by $\mathrm{Na}^{+}$-dependent $\mathrm{Cl}^{-}-\mathrm{HCO}_{3}^{-}$ exchange. J Physiol (Lond) 475:59-67.

Sheldon C, Church J (2002) Intracellular pH response to anoxia in acutely dissociated adult rat hippocampal CA1 neurons. J Neurophysiol 87:2209-2224.

Sheldon C, Church J (2004) Reduced contribution from $\mathrm{Na}^{+} / \mathrm{H}^{+}$exchange to acid extrusion during anoxia in adult rat hippocampal CA1 neurons. J Neurochem 88:594-603.

Sheldon C, Cheng YM, Church J (2004) Concurrent measurements of the free cytosolic concentrations of $\mathrm{H}^{+}$and $\mathrm{Na}^{+}$ions with fluorescent indicators. Pflügers Arch, in press.

Silver IA, Ereciñska M (1990) Intracellular and extracellular changes in $\left[\mathrm{Ca}^{2+}\right]_{\mathrm{i}}$ in hypoxia and ischemia in rat brain in vivo. J Gen Physiol 95:837-866.

Silver IA, Erecińska M (1992) Ion homeostasis in rat brain in vivo: intraand extracellular $\left[\mathrm{Ca}^{2+}\right]$ and $\left[\mathrm{H}^{+}\right]$in the hippocampus during recovery from short-term, transient ischemia. J Cereb Blood Flow Metab 12:759-772.

Sun D, Murali SG (1999) $\mathrm{Na}^{+}-\mathrm{K}^{+}-2 \mathrm{Cl}^{-}$cotransporter in immature cortical neurons: a role in intracellular $\mathrm{Cl}^{-}$regulation. J Neurophysiol 81:1939-1948.

Szabó EZ, Numata M, Shull GE, Orlowski J (2000) Kinetic and pharmacological properties of human brain $\mathrm{Na}^{+} / \mathrm{H}^{+}$exchanger isoform 5 stably expressed in chinese hamster ovary cells. J Biol Chem 275:6302-6307.

Tauskela JS, Mealing G, Comas R, Brunette E, Monette R, Small DL, Morley P (2003) Protection of cortical neurons against oxygen-glucose deprivation and $N$-methyl-D-aspartate by DIDS and SITS. Eur J Pharmacol 464:17-25.

van Emous JG, Schreur JHM, Ruigrok TJC, Van Echteld CJA (1998) Both $\mathrm{Na}^{+} / \mathrm{K}^{+}$ATPase and $\mathrm{Na}^{+} / \mathrm{H}^{+}$exchanger are immediately active upon post-ischemic reperfusion in isolated rat hearts. J Mol Cell Cardiol 30:337-348.

Vergun O, Sobolevsky AI, Yelshansky MV, Keelan J, Khodorov BI, Duchen MR (2001) Exploration of the role of reactive oxygen species in glutamate neurotoxicity in rat hippocampal neurones in culture. J Physiol (Lond) 531:147-163.

Vornov JJ, Thomas AG, Jo D (1996) Protective effects of extracellular acidosis and blockade of sodium/hydrogen ion exchange during recovery from metabolic inhibition in neuronal tissue culture. J Neurochem 67:2379-2389.

White RJ, Reynolds IJ (1995) Mitochondria and $\mathrm{Na}^{+} / \mathrm{Ca}^{2+}$ exchange buffer glutamate-induced calcium loads in cultured cortical neurons. J Neurosci 15:1318-1328.

Wu ML, Tsai ML, Tseng YZ (1994) DIDS-sensitive $\mathrm{pH}_{\mathrm{i}}$ regulation in single rat cardiac myocytes in nominally $\mathrm{HCO}_{3}^{-}$-free conditions. Circ Res 75:123-132.

Yan Y, Dempsey RJ, Flemmer A, Forbush B, Sun D (2003) Inhibition of $\mathrm{Na}^{+}-\mathrm{K}^{+}-\mathrm{Cl}^{-}$cotransporter during focal cerebral ischemia decreases edema and neuronal damage. Brain Res 961:22-31.

Yu SP, Choi DW (1997) $\mathrm{Na}^{+}-\mathrm{Ca}^{2+}$ exchange currents in cortical neurons: concomitant forward and reverse operation and effect of glutamate. Eur J Neurosci 9:1273-1281.

Yu X-M, Salter MW (1998) Gain control of NMDA-receptor currents by intracellular sodium. Nature 396:469-474.

Zhang Y, Lipton P (1999) Cytosolic $\mathrm{Ca}^{2+}$ changes during in vitro ischemia in rat hippocampal slices: major roles for glutamate and $\mathrm{Na}^{+}$-dependent $\mathrm{Ca}^{2+}$ release from mitochondria. J Neurosci 19:3307-3315. 